\title{
A embriaguez no teatro de Shakespeare
}

\author{
A. Almeida Júnior
}

Si Mozart houvesse nascido na Polinésia (a hipótese é de Weismans), não teria composto nem quartetos para instrumentos de cordas, nem sinfonias.

William Shakespeare tambem recebeu dos fados um duplo presente: o seu gênio e a época de Elizabetr.

Época de emoção. Lord Burghiey soubera explorar internamente a ameaça de FELIPE II e manter em persistente vibração o patriotismo britànico. Assim, quando em 1588 a esquadra de Drake e Hawkins queimou, afundou ou dispersou os navios da Invencivel Armada, a notícia da vitória veiu despertar, no povo inglês, a conciência da sua fôrça, e, possivelmente, numa súbita antevisão, mostrar-lhe a magnitude do seu destino histórico ${ }^{\left({ }^{1}\right)}$.

Época de cultura tambem. A trepidação emocional que sacudia o velho tronco em reflorescimento encontrava em tôrno de si espíritos armados para os mais altos feitos da inteligência. 0 exemplo vinha de cima, do trono e da côrte. A rainha Elizabeth conhecia perfeitamente o latim, traduzia o grego, analisava os filósofos, praticava com êxito a literatura. Ao lado dela, uma aristocracia de viva curiosi-

(1) Entre os instrumentos a servico de Burghley, conte-se o "Mercúrio Inglês", o primeiro jornal inģł́s. aparecido em 1588, e cujos artigos $\mathrm{e}$ informações eram habilmente inspirados pelo arguto. ministro de Elizabeth. 
dade intelectual não se degladiava tão só nos torneios de cavalaria: competia igualmente no comentário dos clássisos gregos ou latinos, escrevia versos, discreteava elegantemente nos salões, - fazendo praça de uma forma literária e de uma erudição que tocavam ao pedantismo. Quanto às ciências, a luzida falange de espíritos independentes encabeçada por Francis BAcoN, acoroçoava ou realizava o estudo direto da natureza e defendia com denodo a liberdade de pensamento.

Não se circunscrevia, porém, ao palácio real e aos áulicos, nem se limitava ao grupo dos eleitos da fortuna a preocupação pelo amanho da inteligência. Tambem participavam desse anseio as classes populares. Desenvolverase no país, desde então, um extenso sistema educativo, que alcançava até modestas aldeias, e permitia à juventude inglesa o contacto com preceptores de grande erudição. Havia alguns destes, no fundo da província, que "liam o latim por puro prazer" (2).

Dessa divulgação do ensino (de que se encontram indícios em vários diálogos de Shakespeare), duas consequências resultaram, em relação com a obra do poeta.

A primeira foi a possibilidade de ter sido alcançado pela contaminação cultural um obscuro rapaz nascido em pequenina cidade do país. De fato, em Stratford sobre o Avon foi dado a Shakespeare frequentar a escola durante alguns anos, e, ao que se supõe, ali teve êle os seus únicos estudos regulares (3). Posteriormente, beneficiou-se ainda o joven auxiliar de teatro, da onda geral de intelectualismo que andava pelo ar, onda em que se abeberou com a sofreguidão e a independência peculiares ao gênio.

(2) "Por certo que a sociedade e toda a cultura intelectual da nação ganhou na beleza da forma e na graça do movimento por essa extensa familiaridade com as flores poéticas da literatura clássica" (Hermann Ulrici).

(3) Escapa aos objetivos deste trabalho examinar o árduo problema da identidade de William Shakespeare. 
A segunda consequência das condições suciais foi a formação, no tempo do poeta, de um ambiente que incentivou e compreendeu, ao menos parcialmente, a obra shakespeareana. As produções artísticas, e especialmente as produções de teatro, são como as da flora e da fauna: exigem clima propicio. $\mathrm{O}$ artista totalmente incompreendido pela sua geração poderia começar, mas não prosseguiria no esfôrço creador, por lhe faltar, como estímulo, o éco das vibrações circunstantes. Seria um sino a badalar no vácuo.

Shakespeare teve, pois, do seu meio, de uma parte, o vigoroso abalo sentimental do patriotismo, fortalecido, nele, pela conciência de estar servindo a uma grande nação; de outra, ponderoso lastro de cultura e, em torno de si, um ambiente espiritual em condições de reconhecer as manifestações mais palpáveis do seu gênio. O poeta, em verdade, ultrapassou o seu século e transpôs os mares, para tornar-se o maior intérprete da alma humana eterna e universal. Mas o clima próximo - próximo no tempo e no espaço lhe fora favorável e ensejara, assim, à civilização, uma das suas mais luminosas produções.

\section{OS CONHECIMENTOS MÉDICOS DE SHAKESPEARE}

O grande mistério da vida de Shakespeare é a sua imensa cultura. "William Shakespeare sabe tudo; William Shakespeare leu tudo", exclama Montégut (4). Dentre os conhecimentos científicos que a sua obra literária demonstra, avultam os de natureza médica. Considerando a segurança com que o poeta manuseia as noções desta categoria, certos comentadores chegam a conjecturar que êle tenha seguido cursos especiais da matéria ou que, pelo menos, haja convivido na intimidade de médicos ilustres (5).

(4) Mathias Morhard - A la rencontre de "William ShakesPEARE", Paris 1938, 123.

(5) Hermann Ulrici - History and Character of ShakesPEAre's Plays, trad. inglesa da $3 .^{a}$ ed. alemã, Londres, 1876, I, pag. 259. 
Todos os grandes livros publicados até o seu tempo, sobre assuntos de medicina, repercutem na obra shakespeareana. Numa tese recente da Faculdade de Paris, o dr. ANDRÉ ADNĖs pôde aferir, por método rigorosamente preciso, a abundante erudição do autor de "Macbeth" e do "Rei Lear", no terreno específico da Psiquiatria. O joven médico francês procurou, nas obras científicas anteriores ao século XVII, desde as da antiguidade clássica até as do periodo da Renascença, tudo quanto se escrevera em matéria de loucura. Joeirou, em seguida, um a um, nas creações teatrais do poeta, os tópicos referentes ao mesmo mal. 0 confronto foi o mais lisongeiro possivel para SHaKespeare. "Shakespeare (conclue o autor da tese) dá-nos, sobre a loucura e o seu tratamento na época, a documentação mais completa que possuimos" (6).

Mas não se trata só de leitura. Shakespeare, mais baconiano que BAcon, soube ver por si mesmo os fatos naturais, soube descrevê-los com clareza, chegou até, para explicar alguns deles, a pressentir doutrinas então inexistentes.

As observações psicológicas constituem o fundo principal dos conhecimentos a que deu corpo a arte shakespeareana. Servindo-se delas com maestria, ninguem como ShaKespeare pôde pintar as grandes paixões humanas em movimento, - o amor, o ciume, a cubiça, o ódio traiçoeiro, - ou crear personagens "reais", movidos, não pela força dos deuses, mas pelas virtudes ou fraquezas de cada um.

Ao lado dos magestosos paineis que formam o cabedal mais rico da sua obra literária, aparecem-lhe a cada passo, na sucessão dos diálogos trágicos ou cômicos, argutas notas de psicologia quotidiana, de fisiologia, de patologia, ou o registro de noções e práticas correntes no seu tempo.

A decadência senil é debuxada em traços largos e hábeis nesta réplica do Juiz Superior a João Falstaff, o impenitente devasso que, a despeito dos seus sessenta anos e dos vicios, quer se fazer passar por moco:

(6) Matuiss Monhakdt - op. cit. pag. 128. 
"Não apresentais porventura os olhos úmidos, a mão seca, o rosto amarelado, a barba branca, as pernas encolhidas, o ventre avolumado? Não tendes a voz trêmula, o fôlego curto, o queixo duplicado, a inteligência simples, e todas as vossas facul(iades empobrecidas pela caducidade?"

\section{(2 Henrique IV, I, ii)}

Da velhice patológica, baste lembrar o "Rei Lear", “o mais pungente drama da scnilidade" (ANDré AdNÈs).

Num diálogo de "Véspera de Reis", o poeta consigna a noção talvez corrente em seu tempo da correlação entre a intensidade da sudorése e a das emoções - fato que hoje se aproveita nas provas com o psicogalvanómetro. Maria, querendo fazer ver ao cavalheiro André que ela não está acreditando muito na sinceridade das suas expansões amorosas, declara:

“_ Vossa mão está tão sêca, senhor!"

Ao que o cavalheiro André responde, cheio de subentendidos:

“- Eu o creio, por certo; não sou tão tolo que não saiba conservar as minhas mãos sêcas."

(Véspera de Reis, I, iii)

A tragédia "Coriolano" contém um trecho que acertadamente se aponta como a previsão da teoria circulatória, formulada alguns anos mais tarde por HARvey, embora implícita em obras anteriores. Na conhecida parábola da rebelião dos membros contra o estômago, diz êste àqueles:

“- Mas Iembrai-vos bem de que aquilo que recebo, eu o transmito, pelos canais do sangue, á côrte, isto é, ao coração."

(Coriolano, $I, i)$

O exame de urina para fins de diagnóstico, mal divulgado em Londres naquela época (7), é familiar a SHaKes-

(7) Charies Kinght - The Complete Works of Shakespeare, Historical Plays, N. York. s/ d, 812. 
PEARE, que o subordina tanto à feitiçaria como à medicina. Em "Véspera de Reis", alguns comparsas pôem em confusão a cabeça de Malvólio, insinuando-lhe que a condessa sua ama está morta de amores por êle. Dai uma serie de disparates do infortunado Malvólio, dando ensejo a este diálogo: tiçado!

Maria - Queira Deus que èle não esteja enfei-

Fabiano - Leve a sua água para a feiticeira.

Em "Henrique IV", trata-se de exame por médico de verdade:

Falstaff (ao pagem) — Grande patife, que disse o médico a respeito da minha água?

Pagem - Ele disse, senhor, que a água, em si mesma, era uma água em boa saude; mas a pessoa que a produziu tem mais doenças do que as que êle conhece."

(2 Henrique IV, I, ii)

Shakespeare, ao contrário de Molière, é um defensor de Hipócrates e de Galeno, isto é, da medicina científica; e um inimigo dos charlatães e dos empíricos. A despeito dos "fisiognomistas", que por aquele tempo gozavam de certa voga, afirma, pela boca do rei Duncan, a futura vitima dos traidores Macbeth:

"Não há nenhuma arte que revele, na face, a estrutura da alma."

(Macbeth, I, iv)

Cerimon, de "Péricles, Príncipe de Tiro", ao iniciar os trabalhos de reanimação de Thaisa, em estado de morte aparente, invoca o auxilio de Esculápio (III, ii).

Na comédia "Tudo está bem quando acaba bem", o Rei de França, embora vítima de uma fístula julgada incurável pelos médicos, não quer entregar-se a um pseudo-curandeiro, que promete livrá-lo do mal: 
“- Não posso (diz êle) prostituir minha moléstia incurável aos empíricos".

(Tudo está bem quando acaba bem, II, i)

Não precisamos deter-nos em novos exemplos, para apoiar uma tese que outros já consolidaram. Baste-nos deixar bem claro, - e isso em proveito da parte essencial deste trabalho, - que Shakespeare não foi apenas um instrumento artístico genial a serviço de uma cultura medíocre. Aos dons excepcionais com que nasceu, associou um opulento cabedal de conhecimentos, haurido no convivio com os melhores livros e no contato inteligente com a vida.

O que êsse espírito de eleição viu e sentiu, a propósito do vício porventura mais antigo e certamente mais arraigado na sociedade humana, isto é, a embriaguez alcoólica, é o que pretendemos investigar, nas páginas seguintes.

\section{OS CONHECIMENTOS DE SHAKESPEARE SOBRE A EMBRIAGUEZ}

ShaKespeare descreve com grande segurança o fenómeno da embriaguez e diversos outros efeitos do uso do álcool. Aonde teria êle ido buscar êsses conhecimentos?

Úma das fontes que se lhe póde atribuir é a leitura: "William Shakespeare leu tudo". Até o século XVII, não se havia iniciado, em verdade, o estudo metódico das manifestações fisiológicas ou patológicas do álcool etilico, inauguradas, ao que parece, entre 1600 e 1700 , por Camerarius (8),

(8) Encyclopédie d'Hygiène et de Médecine Publique - dir. Jules Rochard, Paris, 1897, II, 616. “Já em 1699 Camerarius estudava a ação fisiológica do álcool etílico”, diz, nessa obra, M. Riche, sem dar nenhuma outra informação. Entre 1665 e 1721, viveu Rodolfo Jacob Camerarius, médico e botânico alemão, professor de Medicina em Tubingia. 
e por Jean Morin (9). Mas Hipócrates e Galeno, que Shakespeare admira, aludiam às consequências do uso das bebidas; filósofos e literatos da antiguidade greco-latina, tais como Platão, Aristóteles, Lucrécio, Horácio, Plínio e Plutarco, se tinham ocupado do assunto; Petrarca, no século XIV, descrevera em carta o estado de embriaguez (10); Montaigne, no século XVI, consagrara ao vício um longo capítulo dos seus "Ensaios" (11). Deste último autor, podese afirmar com segurança que Shakespeare o leu, pois não só possuia um exemplar da famosa obra do escritor francês, como o copiou, quasi que palavra por palavra, em um trecho de "A Tempestade" (12).

O banquete de "Timão de Atenas", fartamente regado de vinhos, demonstra que o poeta estava bem informado a respeito dos hábitos dos Gregos, neste particular. Tambem a descrição da festa realizada na galera de Pompeu, próximo ao cabo Misena, prova que o autor de "Antônio e Cleópatra" conhecia os famosos desregramentos báquicos dos Romanos.

Mas a contribuição dos autores antigos em relação à embriaguez, é mais descritiva do que crítica. A antiguidade, dí-lo Montaigne, “n'a pas descrié ce vice; les escripts

(9) Mrguel A. Alvarado - El Alcoholismo ante el Derecho Penal, tese da Fac. de Cienc. Jurid. e Soc. da Guatemala, 1934, 69. A referência a JEAN MORIN, que em 1612 teria "descrito os acidentes alcoólicos, dividindo-se em agudos e crônicos", vem desacompanhada de qualquer outra indicação. Não será Joño Batista Monin, que tomou grau de medicina no ano de 1613, em Avinhão, e morreu em 1656 ?

(10) Adolfo Zerboglio - L'Alcoolismo, studio sociologico-giuridico, Turim, 1892, pag. 26. O autor transcreve a carta de Petrarca.

(11) Montaigne, - Essais, liv. II, cap. ii.

(12) Em "A Tempestade" (I, ii) Shakespeare transcreve um trecho dos "Ensáios" (liv. I, cap. XXX, Des Cannibales), em que Montaigne relata a organização e a vida dos habitantes de l'endroict où Villegaignon print terre, qu'il surnomma la France antartique". Os nossos Tamôios têm portanto a honra de figurar em duas grandes obras da literatura universal: nos "Ensáios" de Montaigne, c no drama que se considera como "o testamento espiritual de SHAKESPEARE". 
mêmes de plusieurs philosophes en parlent bien mollement". Bem outra, como se verá, foi a atitude de Shakespeare.

Certo é, ainda, que o poeta, observador minudente e perspicaz, muito aprendeu no convívio diuturno da cidade. Em Londres, por aquele século, os "casos clínicos" de bebedeira perambulavam em profusão nas ruas e formavam a fáuna específica das tavernas. Na célebre Mermaida, frequentada até pelo favorito RALEIGH, escritores e atores saboreavam "as melhores ostras do tempo", banhadas no vinho da casa, o "famoso vinho Mermaida" (13). Ali tinha Shakespeare ponto de encontro com seu colega e rival BeN Jonson; ali se esgrimiam os dois brilhantes espíritos: BEN Jonson, "sólido mas vagaroso nos seus ataques"; SHakesPEARE, leve, pronto na réplica, capaz de "tirar proveito de todos os ventos" pela agilidade de sua inteligência e pela viveza de sua imaginação (14).

As observações de Shakespeare referentes á ação do álcool, mais reais que as de BAcon, escapam aos erros explicativos deste filósofo. E' interessante notar - especialmente para os que querem atribuir ao autor do "Novum Organum" a obra shakespeareana - que nenhuma das extravagantes interpretações de $\mathrm{BACON}$ a respeito dos efeitos do vinho encontra éco no teatro de Shakespeare (15).

Leitura de autores e observação da embriaguez alheia não faltaram, portanto, ao poeta. E' auto-observação? Teria o creador de Falstaff experiência pessoal dos efeitos das bebidas?

(13) T. Fairman Ordish - Shakespeare's London, Londres, 1897,240 a 244 .

(14) Thomas Fuller, contemporâneo de Shakespeare, in Fairman Ordish, op. cit., $\mathrm{xxx} 244$.

(15) Francis Bacon - Sylva Sylvarum sive Historia Naturalis, ed. inglesa de 1824, I vol., pags. 496 e segs. Bacon considera o vinho perigoso para os indivíduos "sêcos", mas vantajoso para os "úmidos"; explica a embriaguez pela incompatibilidade entre o espírito do vinho e os espíritos animais; julga as pequenas doses repetidas mais embriagantes que uma grande dose única, atribuindo êste fenômeno à maior rapidez com que aquelas enviam vapores ao cérebro; etc. 
A impressão dos biógrafos é que, sem ter sido propriamente abstêmio, Shakespeare, durante a sua fase de produção artística, usou do álcool com muito comedimento. "A despeito das companhias, o poeta não teve em Londres vida de vicios", afirma Ulrici (16).

No declínio, recolheu-se SHakespeare à sua terra natal, suspendeu a atividade literária e, desde então, ao que parece, não fez muita cerimônia com o álcool. "Estimulado pelo colega BEN Jonson", teria êle ficado, várias vezes, "um pouco mais do que tonto pelo copo", E o livro de notas do rev. JoHN WARD, pastor de Stratford, registra que ShaKespeare morreu de moléstia contraida durante "uma partida alegre" com Drayton e Ben Jonson, na qual os convivas "bebreram demais". Contudo, esta suposição parece gratúita e em grande parte inspirada por melindrosa desconfiança de puritano. Mais provavelmente, William ShaKESPEARE foi vítima de doença infectuosa (17).

\section{A EMBRIAGUEZ NO TEMPO DE SHAKESPEARE}

Não cabe aqui o histórico do alcoolismo na antiguidade (18). Os Gregos do tempo de Homero já se embriagavam, e por isso Shakespeare não incide em anacronismo quando faz dizer a Cressida, durante o cerco de Troia, que Ajax não se embriaga.

Os costumes dissolutos dos Romanos, que Horácio, Plínio, Marcial, Suetônio e Juvenal pintaram ou satirizaram (19), se revelam, em amostra, no banquete da galera de Pompeu, figurado no segundo ato da tragédia "Antônio e Cleópatra" $\mathrm{O}$ vinho corre com fartura; os brindes se su-

(16) Hermann Ulrici - op. cit. pag. 260.

(17) Halliwell-Phill|ps - in The Complete Works of Shakespeare, Irving e Marshall, VIII, xxxiii.

(18) Consulte-se Adolfo Zerbogrio, op. cit.

(19) Veja-se A. Carré, L'Hygiène et la Santé dans la Rome Antique, Paris, 1933. 
cedem; alguns convivas, provavelmente, querendo beber ainda mais, praticam na garganta a tradicional "titilatio" Ahenobarbus se mostra em cena; o mesmo Ahenobarbus que matou um liberto porque êste não bebia bastante (20). Cesar, - o futuro Augusto, - embora, como diz, "preferisse jejuar durante quatro dias a beber tanto em um só", dobra-se às injunções sociais, corresponde às saudes que lhe levantam. Passa o triúmviro Lépido, no terceiro grau de embriaguez, carregado por um escravo. E Marco Antônio, "o campeão dos bebedores latinos", propõe, afinal, que todos dansem segurando-se pelas mãos, até que o vinho triunfante venha mergulhar os seus sentidos "em uma doce e deliciosa letargia" ("Antônio e Cleópatra", II. vii)

Para os ingleses do tempo de Shakespeare, os alemães seriam os maiores beberrões da Europa. Dos alemães do século XVI, dizia Montargne, nos "Ensaios": "Os alemães bebem quasi indiferentemente de qualquer vinho com prazer; seu propósito é mais ingerir do que saborear" Com essa irreverência do escritor francês está de acordo a graciosa Portia do "Mercador de Veneza" O pai de Portia decidira que os candidatos à mão da filha se submetessem a uma espécie de sorteio. A cada um deles. isoladamente, scriam apresentados três cofres, - um de ouro, outro de prata, o terceiro de chumbo, - para que escolhesse. Em um dos cofres estava o retrato da moça; e o candidato que acertasse seria o preferido. Daí o seguinte diálogo, em que Portia e sua ama Nierissa trocam impressões a respeito dos vários pretendentes:

Nerissa - Como achais o joven alemão, sobrinho do duque de Saxe?

Portia - Repugnante pela manhã, quando está em jejum; mais repugnante ainda ̀̀ tarde, quando está embriagado.

(20) A. Carré, op. cit. pag. 87. 
Nerissa - Si êle se candidatar à prova e escolher o cofre premiado, recusareis, então, cumprir a vontade paterna, negando-vos a casar-vos com êle?

Portia - Por isso, pelo receio de uma infelicidade, coloca, eu te peço, um grande copo de vinho do Reno sobre o cofre oposto: porque quando o patife entrar, si essa tentação lhe aparecer, estou certa de que êle a preferirá. Farei tudo que puder, Nerissa, para escapar de me casar com uma esponja".

\section{(O Mercador de Veneza, I, ii)}

Parece que os alemães realmente se salientavam, naquela época, como bebedores insignes. Outros autores, mencionados por Marshall (21), reforçam os dizeres de MoNtaigne e de Shakespeare, confrontando, algumas vezes, a borrachice germânica com a sobriedade espanhola. Na opinião de Middleton, seria "tão raro encontrar-se um espanhol beberrão como um alemão sóbrio" Thomaz Browne refere-se a "o espanhol soberbo e o alemão bêbado" Coincide com tais depoimentos o texto dos estatutos elaborados em 1610 pelo conde palatino Frederico V, para regerem a conduta dos membros de uma Sociedade de Temperança. Os artigos principais eram êstes:

1. Compromisso do sócio de abster-se, por dois anos, de qualquer embriaguez completa.

2. Obrigação de não beber mais de sete copos de vinho em cada refeição nem mais de quatorze copos por dia.

3. Para satisfazer a sêde ainda restante, permite-se, alem de água mineral, cerveja.

4. Alem disso, não se autoriza sinão um único copo de aguardente ou outra bebida distilada (22).

Os holandeses estavam, na opinião inglesa, emparelhados com os alemães:

(21) Iriving e Marshall - The Works of Shakespeare, Londres, 1888 , VI, 87.

(22) Giovanni Allevi - L’Alcoolismo, Milão, 1906, 15. 
"Na Alemanha e na Holanda, a intemperança é
vantajosa; e quem mais bebe é quem mais merece"

Os dinamarquêses, severamente apostrofados por SHAKESPEARE no 1. ato de "Hamlet", disputavam galhardameno ceptro aos alemães e aos filhos dos Paises Baixos. As estatísticas de dois séculos mais tarde conferiam-lhes a palma da vitória, pois, atribuindo o consumo anual, per capita, de 3 litros de álcool à Inglaterra, de 8 litros à Alemanha e de 9 à Holanda, davam à Dinamarca 18 litros (23).

Tambem era coisa resolvida, entre os inglêses de EurzABETH e JAIME I, que a sua embriaguez fora aprendida com os holandêses. "O excesso nas bebidas (escrevia Pennilesse em 1595) é um pecado que, desde quando nos puzemos em contacto com os Paises Baixos, passou a considerar-se honroso; mas antes de conhecermos suas demoradas guerras, era tido no mais alto grau de aversão possivel. Então, si vissemos um homem extendido na rua, ou jazendo a dormir sob a mesa, teriamos cuspido de escárneo e afastado de sua companhia todos os nossos amigos" No mesmo sentido escreveu Peachem, em 1622: "Mas desde que tivemos de intervir nas guerras dos holandeses,. o costume de beber e levantar brindes se transportou para a Inglaterra". E CANDEM, em sua "História da rainha Elizabeth", declara que "os inglêses, em suas longas guerras na Holanda, começaran a embriagar-se com excesso de bebidas; e, bebendo à saude de outros, puzeram-se a prejudicar a sua própria saude. Entre todas as nações setentrionais, êles eram, antes disso, louvados pela sua sobriedade" (24).

(23) Encyclopédie d'Hygiène et de Médecine Publique, dir. Jules Rochard, art. de M. Riche, Paris, 1897, II, 735 e segs. Presentemente, os dinamarqueses se incluem entre os povos mais sóbrios da Europa, consumindo cerca de 2 litros de álcool por ano e por cabeça.

(24) I. D'Israeli - Curiosities of Literature, Paris, 1835, II, 252 a 260. 
Um primeiro fato pode-se, entretanto, assegurar, e é que no tempo de Shakespeare os inglêses cultivavam largamente o vicio da embriaguez. O viajante veneziano MoLINA, passando em 1607 por Londres, depõe: o vicio da embriaguez é geral (25). O próprio Pесснам, que explicara a embriaguez de seu povo pelo contacto com a Holanda, pondera, em 1622: "deixemos que o holandês seja o seu próprio juiz, para decidir si nós o igualamos ou não; quanto a mim, julgo que o ultrapassamos" (26). Iago não pode, portanto, instilar muita ironia em suas palavras quando, no segundo ato de "Otelo", faz o louvor da valentia inglêsa em matéria de capacidade etílica. Referindo-se a uma canção báquica que acaba de cantar, assim se expressa o pérfido soldado:

"Aprendi-a na Inglaterra, onde a gente é mestra em beber. Vossos dinamarquêses, vossos alemães e vossos holandêses barrigudos. não valem nada em comparação com os inglêses"

(Otelo, II, iii)

Demais, deve-se pôr em dúvida a sobriedade dos inglêses antes do seu contacto bélico com a Holanda. A 26 de maio de 946, Edmundo I, rei dos Anglo-Saxões, celebrou a festa de Santo Agostinho em Gloucertershire; os nobres e cortezãos ficaram tão alcoolizados que não se incomodaram com a entrada de um ladrão na sala do bródio. 0 ladrão agrediu o rei e acabou matando-o, sem que os convivas interviessem ou siquer perseguissem o criminoso (27).

Um antigo costume era o de beberem todos em um grande vaso comum, que girava em torno da mesa. Cada qual tomava o seu trago, e chamava-se a isto um "carouse" Pois tanto se repetiram os conflitos por causa do tamanho dos goles, que o rei EdGard (959-975) se viu obrigado a disciplinar a circulação do grande copo e a man-

(25) HermanN Ulrici - op. cit. I, 181.

(26) L. D'Israeli - op. cit.

(27) Áolfo Zerboglio - op. cit., pag. 24. 
dar marcar, com pinos bem vísiveis, os limites das doses de cada um (28).

As distribuições públicas de bolos e de "ale", feitas nos dias de festa, já representavam um costume imemorial, quando, no tempo de Shakespeare, foram denunciadas pelos puritanos como prática papista (29).

Por fim, a intervenção legislativa patenteia ainda que desde meiados do século XVI, o poder público procurava freiar a intemperança alcoólica. Um ato do governo de MARIA Tudor, em 1552, previa a aplicação de penas a quem, em sua casa, levasse alguem a embriagar-se. E o Estatuto de Jaime I, de 1607, em vida ainda de Shakespeare, pune o indivíduo embriagado com a multa de cinco "shillings", ou com a permanência no tronco durante seis horas; pois a lei (pondera um comentador) presume que, passado êsse lapso de tempo, o infrator tenha recuperado os sentidos e deixado de ser perigoso $(30)$.

\section{A ADEGA SHAKESPEREANA}

A bebida popular, na época de Shanespeare, era a cerveja, ou "ale", aprendida com os Romanos. Fabricavam-na os particulares e tambem os monastérios, mas no século

(28) “O rei EDgARD, para que os seus súditos não se agredissem mutuamente, nas orgias e bebedeiras, como faziam, determinou que certas canecas de ferro fossem acorrentadas em cada bebedouro e à porta de cada taverneiro, com pinos de ferro no seu interior, para marcar a cada homem a dose que êle devia beber, e aquele que ultrapassasse o respectivo pino pagava a multa de um peni por dose" (Tom Nash). Ao que afirma Pegge, havia "a gill of ale" (cerca de 120 centímetros cúbicos) entre um pino e outro. Nos cânones do arcebispo ANselmo, de Londres (1102), os padres são convidados a abster-se desses hábitos: "Ut Presbyteri non eant ad potationes nec ad pinnas bibant" (L. D'Israeli, Curiosities of Literature, Paris, 1835, II vol. pag. 256).

(29) Françors Victor-Hugo - Oeuvres complètes de ShakesPEARE, XIV, 412.

(30) William BlascKstone, - Commentaries on the Law of England, Londres, 1787, IV, 26. 
XVII começaram a desenvolver-se as cervejarias. Da indústria doméstica ainda nos dá notícia uma referência de "Sonho de uma Noite de Verão" A fada, dirigindo-se ao travesso e malicioso Puck, diz-lhe:

\author{
"Não é porventura vucè quen assusta as rapa- \\ rigas na aldeia.. e quem impede a bebida de \\ fermentar?"
}

(Sonho de uma Noite de Verão, I, iii)

A designação antiga era "ale" e correspondia à bebida fermentada obtida comumente da cevada, sem lúpulo. Quando, no século XVI, se começou a usar lúpulo, a palavra "beer" foi sendo gradualmente introduzida para significar o novo tipo. Na época de Shakespeare, "ale" era uma cerveja clara, amarelada, transparente, sem amargor, com pouco lúpulo. Chamava-se simplesmente "ale", quando rica em álcool; e "small ale", cervejinha, quando fraca. As duas expressões - "ale" e "small ale" — se encontram igualmente em Shakespeare. "Beer" é menos frequente.

A cerveja, e, mais ainda, a cervejinha, eram a bebida do povo. A popularidade desta última advinha menos das suas qualidades intrínsecas que do seu preço. O demagogo e revolucionário Jack Cade, na arenga com que pretende inflamar os seus adeptos, apresenta um grande plano de reformas administrativas e sociais: "todos os bens serão comuns"; "todos comerão e beberão à minha custa"; "todos andarão vestidos do mesmo modo, para que pareçam irmãos;" "mataremos todos os juristas" E põe mais êste tópico no discurso:

"Haverá na Inglaterra sete pães de meio "penny" vendidos por um "penny"; as vasilhas de três medidas terão dez medidas; e eu considerarei crime beber cervejinha."

(2 Henrique IV. IV, ii)

Gregos e Romanos achavam que só o vinho fica bem para os civilisados: cerveja é bebida de bárbaros. 0 pre- 
conceito aparece no teatro de Shakespeare. O príncipe Henrique, herdeiro da corôa e grande consumidor de vinho espanhol, frequentador de tavernas e amigo de aventuras, não esquece a sua prosápia:

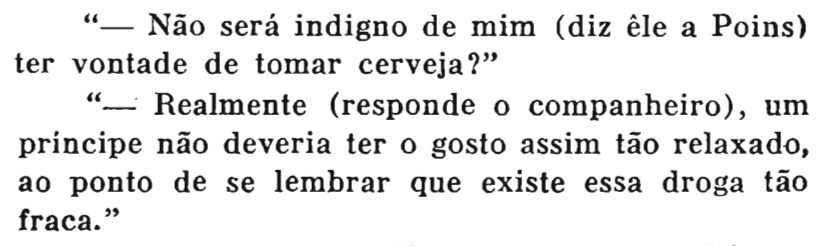

(2 Henrique IV. II, ii)

A bebida dos ricos e dos nobres é o vinho. Usa-o o rei da Dinamarca, em "Hamlet"; emprega-o, nos brindes e nos crimes, o casal Macbeth; bebem-no os altos oficiais de "Otelo" e os seus convivas; infiltra-se dele o gordo Falstaff, companheiro do príncipe Henrique. Cristovam Sly, o caldeireiro borracho de "A Megera Domada", declara, em casa do "lord":

\section{"nunca bebi vinho em minha vida"}

Os inglêses não fabricavam vinho; à tentativa da idade média, no sul do país, faltara continuação. Todo o vinho bebido no tempo de Shakespeare e nas suas peças teatrais, procede do extrangeiro.

O vinho mais frequente é o "sack", isto é, o vinho espanhol. "Sack", diz um comentador do poeta, "era o nome dado a todos os vinhos espanhóes, os quais, em regra secos e ásperos, requeriam fossem abrandados com açúcar, afim de atenderem ao paladar da época" (31). A etimologia de "sack" não é pacífica: para uns, a palavra vem de "sêco", adjetivo que alude ao tipo do vinho; para outros, vem de "saco", porque a principio o vinho espanhol era guardado em sacos de couro. Falstaff consome o xerez, como "sack" predileto.

(31) Inving e Marsiyall - op. cit. III, 392, 393. 
O vinho das Canárias pertencia tambem ao grupo dos "sacks" de Espanha, e a desabusada taverneira d"A Cabeça de Javali" o menciona expressamente quando diz:

"bebestes muito vinho das Canárias; é um vinho maravilhoso e penetrante, que perfuma rapidamente o sangue".

(2 Henrique IV II, iv)

Dos vinhos portuguêses, encontramos referência a dois. Poins, ao dar certa vez com Falstaff, interpela-o:

"Como te arranjaste com o diabo, a propósito de tua alma, que lhe vendeste na última sexta-feira santa, por uma taça de vinho Madeira e uma perna de frango?"

(2 Henrique IV. I, ii)

A freguesia de Charneca, nas vizinhanças de Lisboa, produzia um vinho então famoso, e que na boca dos ingleses ficou sendo o "charneco":

"Eis aqui, meu vizinho, (diz um personagem), eis aquí uma taça de charneco".

(2 Henrique VI, II, iii)

Dos vinhos alemães, cita-se nominalmente o do Reno. E' com êste vinho que a ardilosa Portia, do "Mercador de Veneza", quer distrair o pretendente indesejado. E Hamlet assim ridiculariza os brindes do rei seu tio:

"E cada vez que êle ingere um trago de vinho [do Reno.

Os timbales e trombetas celebram

o triunfo do seu brinde".

(Hamlet, I, iv)

Quanto aos vinhos francêses, a rapariga da taverna “A Cabeça de Javali" lembra o de Bordéus, quando diz, a propósito de um borracho: 
"Há nele toda uma carregação de Bordéus"

(2 Henrique, IV, II, iv)

Dos vinhos mais antigos, faz-se explícita referência ao vinho grego, com que Aquiles, em "Troilus e Cressida", pretende aquecer o sangue de Heitor.

Através de Shakespeare, é possivel ainda ter-se idéia do preço do vinho espanhol na taverna frequentada por Falstaff. Falstaff ceiou, recebeu a conta e dormiu. $O$ principe mandou revistar-lhe os bolsos, encontrando-se então esta curiosa nota de despesas:

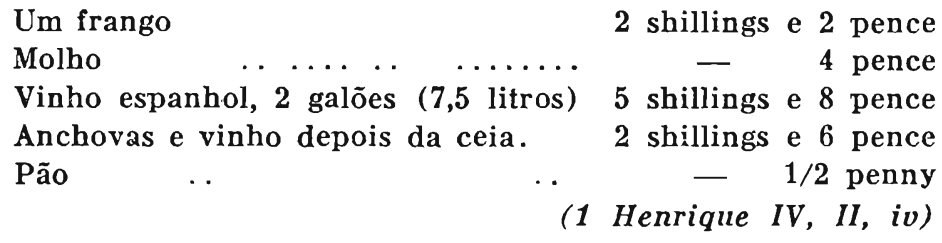

O principe Henrique achou essa conta monstruosa: para mais de dois galões de vinho, apenas meio "penny" de pão!

Bebia-se tambem um vinho sem marca, um "castanho bastardo" que, pelo nome e pela forma pejorativa por que a êle se refere o entendido herdeiro da corôa, seria uma zurrapa qualquer. Diz o príncipe a um criado:

\section{"o teu castanho bastardo é a tua única bebida" (1 Henrique $I V, I I, i v)$}

Já naquele tempo se adulteravam os vinhos com gêsso. Queixa-se disso Falstaff:

"Velhaco! Há gêsso neste vinho espanhol. Só se encontra velhacaria nos vilões. E um covarde é pior do que um copo de vinho com gêsso".

(1 Henriaue IV. II, iv)

Cerveja e vinho são, pois, as duas bebiđas em uso franco, no tempo de Shakespeare e no seu teatro. Mas a aguarCoul. 8. 
dente, isto é, o "brand-wine" (vinho "queimado", ou vinho "que queima") já despontara no horizonte báquico. Iniciara-se em 1514, no continente, a sua venda muito discreta pelos negociantes de vinho e distiladores; mas desde 1524 o margrávio de Esse, na Alemanha, era obrigado a proibirlhe o comércio. Em 1581, os inglêses, pela primeira vez na história, forneceram aos seus soldados em operações nos Paises Baixos, uma ração de aguardente (32). Em 1622, segundo se depreende de um tópico de JoHn Fletcher (33), vende-se "brand-wine" em Londres. Em 1627, no Piemonte, Carlos Manoel procura coibir a distilação (34). E em 1650, já se distila francamente no Brasil, na Capitania de São Paulo (35).

Esses marcos cronológicos da vida da aguardente mostram que a era de Shakespeare foi tambem a do advento das bebidas distiladas. Mas o poeta, que desde 1601 restringira a sua atividade, e provavelmente não escreveu mais depois de 1610 , ficou apenas no vinho e na cerveja. $A^{\prime}$ "aqua vitae" e à sua fabricação faz seis ou sete referências, mas não como bebida popular. Lady Macbeth aludindo aos camareiros do rei Duncan, aos quais pretende adormecer pelo vinho, recorda o alambique (Macbeth, $I$ vii).

Menção expressa da aguardente se encontra na "Comédia dos Enganos", mas o produto aí se alista como medicamento. De fato, foi sob o manto benévolo da terapêutica que a "água da vida" se insinuou nos hábitos humanos. Drômio de Siracusa e seu amo vão viajar por mar; Drômio, declara haver comprado.

(32) J. Rochard - Traité d'Hygiène, Paris, 1897.

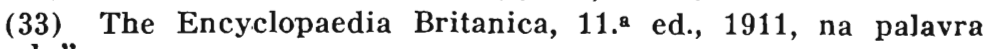
"brandy".

(34) Adolfo Zerboglio, op. cit., 159.

(35) A. Almeida Júnion - Rev. Fac. Dir. S. Paulo, XXX, ii, abril-junho 1934 .

Em interessante artigo do "Estado de S. Paulo" (4-12-38), Nuto San'AnNa mostra que em 1638 já se vendia aguardente em S. Paulo, e em 1656 era proibida a importação desse produto, em beneficio do que se fabricasse na terra. 
"o óleo, o bálsamo e aqua-vitae".

(Comédia dos Enganos, IV. i)

Ainda como estimulante para reanimar pessoas em deliquio, a "aqua vitae" aparece em "Conto de inverno" (IV, iii) e em "Romeu e Julieta" (II, ii e IV, v).

As parteiras do tempo de Terûncio, em Roma, tinham a fama de grandes amigas de bebidas (36). Daí, talvez, e do uso medicinal da substância, uma frase de Shakespeare, em "Véspera de Reis". Maria teceu complicada intriga para fazer que Malvólio se supuzesse amado por Olívia. Malvólio deixou-se enredar na trama. Maria e Tobias conversam sobre o caso:

Tobias - Mergulhaste-o num sonho. Quandu - sonho se desfizer, êle se tornará maluco.

Maria - Dizei a verdade: a intriga produzirá efeito?

Tobias - Como aguardente em uma parteira.

(Véspera de Reis, II, v)

Finalmente, num cantinho de adega provinciana vamos encontrar um discreto frasco de aguardente, - de aguardente de beber, - guardado com a maior reserva. Ford, suspeitando que sua mulher atende aos galanteios de Falstaff, exclama:

"Prefiro confiar minha manteiga a um flamengo; meu queijo a Parson Hugh, o galês; minha garrafa de aguardente a um irlandês, meu cavalo de sela a um ladrão, a deixar minha mulher confiada à sua própria guarda".

(As Alegres Comadres de Windsor, II, ii)

Passamos em rápida revista a adega shakespeareana. Nela encontramos vários tipos de cerveja e algumas marcas de vinhos extrangeiros. Cerveja para os pobres; vinho

(36) A. Carré - op. cit., 93. 
para os ricos. As bebidas distiladas ensaiam timidamente os seus primeiros vôos. Nos séculos seguintes, pela sua força de penetração e de nocividade, serão elas que dominarão o quadro da embriaguez.

\title{
COMO E ONDE SE BEBIA
}

O hábito das "saudes", a despeito da opinião de PEAcham, que o supunha aprendido dos holandêses, vinha de longe. A palavra "rouse" designava o conteúdo de um grande copo, bebido a título de brinde. "O rei toma o seu "rouse", isto é, bebe à saude, afirma Hamlet. Os amigos "já me deram um "rouse", declara Cássio, em "Otelo"

Quando o mesmo copo passava de mão em mão, em torno da mesa, tinha-se um "carouse" O porteiro de Macbeth, ao lhe perguntarem porque se levantou tão tarde, responde:

\author{
"Estivemos fazendo "carouse" até o segundo \\ canto do galo".
}

(Macbeth, II, iii)

Não podia haver "rouse" sem que o copo ficasse inteiramente vasio. Daí a curiosa divisa das funções báquicas: "drinking super nagulum" "Beber sobre a unha" consistia em exgotar o copo e, a seguir, inverte-lo de modo que o liquia porventura restante escorresse sobre a unha e ai formasse apenas uma gota, uma "pérola". Si, pelo fato de haver sobrado muita bebida no copo, não pudesse formarse a pérola, o brinde não teria sido válido e era preciso recomeçar (37).

Um elegante e aristocrático costume - o de lançar pérolas no copo em que se bebia à saude de alguem - pa1898.

(37) Pierce Penllesse - Nash, in The Century Dict., N. Y., 
rece ter sido imitado da rainha Cleópatra (38). Eis as palavras com que o rei Cláudio, no último ato de "Hamlet", procura disfarçar a mistura de veneno no vinho que vai dar ao sobrinho:

“O rei beberá pelo melhor alento de Hamlet;

E na taça uma pérola irá lançar,

Mais rica do que a que quatro reis sucessivos

Usaram na corôa da Dinamarca".

$O$ duelo entre Hamlet e Laerte se inicia. O rei, para fingir que se interessa pela vitória do sobrinho, e para estimulá-lo, exclama:

"Hamlet, esta pérola é tua. Bebo à tua saude".

Mas a rainha, a mãe de Hamlet, tambem quer brindar o filho; e como ignora a trama criminosa, bebe justamente do vinho envenenado. Cáe imediatamente, e, denunciando a bebida fatídica, morre. Informado da traição, Hamlet fere o rei com a espada e ainda o obriga a esvasiar o copo homicida, dizendo:

“Toma, incestuoso, assassino, réprobo dinamarquês; Bebe êste veneno: está nele a tua pérola?"

(Hamlet, $\mathrm{V}$, ii)

Bebia-se a domicílio: os pifões dos cavalheiros Tobias e André, em "Vésperas de Reis", são sempre de portas a dentro. Mas as tavernas já representavam uma instituição an-

(38) Plínio - Hist. Nat., trad. franc. de E.. LitTré, liv. IX, lviii: "Ela (Cleópatra) trazia nesse momento essas duas pérolas, obra prima singular da natureza, e verdadeiramente sem semelhante. AnTônio observava o que ela ia fazer: a rainha tira uma, lança-a no vinagre, fa-la dissolver-se e a ingere", lix: "Entretanto, ANTòNio e Cleópatra não terão a palma da prodigalidade, e serão despojados mesmo dessa glória. Antes deles, iisto tinha sido feito com pérolas de grande valor por Cuódrus, filho do ator trágico Esopo, que lhe havia deixado em herança uma grande fortuna". Note-se, todavia, que o vinagre não ataca as pérolas com a rapidez pressuposta na narrativa de Plínio. 
tiga. Deveriam ter grande sedução essas casas de bebidas, as "ale houses", porque é justamente delas que se lembra o pagem de Falstaff, no momento em que o horrorizam as cenas de batalha, diante de Harfleur:

"Quizera eu estar numa casa de cerveja, em Londres! Eu trocaria de bom grado toda a glória por um copo de cerveja, e segurança".

(Henrique V. III, i)

Distinguiam-se as casas de cerveja por suas rótulas vermelhas. O pagem conta a Bardolfo que o seu amo o chamou de dentro de uma "ale house":

"Ele me chamou ainda agora, senhor, através de uma rótula vermelha"

(2 Henrique IV II, ii)

A mais célebre taverna da vida real de Shakespeare foi a Mermaida. A mais famosa do seu teatro foi a "Cabeça de Javali”, cuja estalajadeira, a senhora Quickly, teve a honra insigne de assistir o cavalheiro Falstaff, em sua morte melancólica. $\mathrm{Na}$ "Cabeça de Javali", frequentada até pelo principe de Gales, reuniam-se em torno de Falstaff os seus comparsas Bardolfo, Nym, Pistol e outros. Honrava-os algumas vezes Doll Tearsheet, dama de costumes suspeitos. Nas noites escuras de Londres, esta turma de foliões, iluminada pelo nariz incandescente de Bardolfo, percorria as ruas, de taverna em taverna, a esvasiar copos de vinho espanhol e a abastecer a cidade com o espírito faiscante e inexgotavel de Falstaff.

Vendia-se a bebida aos galóes e às quartas (39). Para o vinho, usavam-se tambem potes de duas quartas. Falstaff, depois da malograda conquista que empreendeu junto à se-

(39) O galão de vinho equivalia a quasi quatro litros $(3,785)$; o de cerveja, maior, correspondia a 4,620 . Cada galão contém quatro quartas. 
nhora Ford, e do pavoroso banho no Támisa que disso resultou, chega à taverna, enregelado, e pede vinho:

\section{Espanha” \\ “- Vai buscar-me, uma quarta de vinho de}

O malaventurado cavalheiro ainda estremece de indignação e de horror, ao recordar o perigo por que passou. Jogá-lo n'água, a êle, que, pela sua massa, tem uma tendência natural e invencivel para afundar! Demais, a morte por afogamento é, em si mesma, desgraciosa:

“a água nos incha; e que seria eu, depois de afogado? seria uma montanha de carne".

Vem o vinho; Falstaff despeja-o pela garganta abaixo, "para misturá-lo com a água do Támisa" Mas a dose nã o satisfaz, pois logo após reclama:

“- Leva embora esses cálices e prepara-me um pote de vinho de Espanha especial.

- Com ovos, senhor? (pergunta Bardolfo).

- Simples (responde Falstaff). Não quero esperma de galo em minha bebida".

(As Alegres Comadres de Windsor, III, v)

\section{OS BÊBADOS DE SHAKESPEARE}

A embriaguez nada crêa: liberta apenas aquilo que a timidez, as convenções sociais, a educação haviam represado. Dissolvido no álcool o verniz dessas inhibições, a alma humana se desnuda ao sol, com suas chagas e deformidades, mostrando em tumulto as suas tendências inferiores. "In vino veritas".

A embriaguez incipiente atua, pois, de certo modo, como um revelador: mostra-nos o homem "ao natural", sem a casca das imposições sociais. Sendo os homens nativamente diferentes uns dos outros, os bêbados tambem diferem 
entre si. A desigualdade que existe perante o álcool, e da qual nos fala LASÈgue, nasce da desigualdade que existe antes dele.

Shakespeare terá que expor-nos, portanto, uma galeria de bêbados em que cada um difira de si próprio, do seu "eu social", por causa do álcool, e em que uns difiram dos outros em virtude das suas peculiaridade individuais.

Convém notar tambem que o álcool é deprimente para o cérebro desde as gotas iniciais que atingem êsse órgão. Como primeiro ef eito - o ef'eito das pequenas doses, - paraliza a repressão e a crítica, solta a lingua, desgoverna a imaginação, liberta a agressividade instintiva. Daí uma enganosa aparência de estímulo, - êsse estado de excitação hipomaníaca que mergulha o alcoolizado na euforia e, acelerando o ritmo do pensamento inferior e da motricidade incoordenada, ilude observadores menos prevenidos.

Vamos à galeria báquica de Shakespeare. Comecemos no degrau inferior da escala.

Cristovam Sly é o caldeireiro borracho de "A Megera Domada" Aparece apenas na introdução da comédia, episodicamente, e, já em marcha acelerada para a fase terminal da embriaguez. Quebra copos na taverna; insulta grosseiramente a taverneira, recusa-se a pagar a conta, vocifera, e, daí a pouco, está a dormir no chão da rua como um suino. A reação de Cristovam Sly ao álcool marca o nivel da sua mentalidade e patenteia algumas de suas tendências inferiores: destruir, insultar, não pagar.

Levam o caldeireiro ao palácio do "lord"; vestem-no ricamente, e, quando desperta, mal curtido ainda da bebedice, os pagens o convencem facilmente de que êle próprio é um rico "lord", casado com uma "lady" muito bonita. Dois grandes desejos, então, ali mesmo, simples, instintivos, naturais, lhe sacodem "a carne e o sangue": beber um copo da bebida de todos os dias, e servir-se da sua nova mulher: 
"Que tragam aqui a nossa dama; mas não se esqueçam: que venha tambem um pote de cervejinha”.

(A Megera Domada, Introd., ii)

Cristovam Sly é um tipo de bêbado vulgar, - vulgar como a sua pobreza mental, - um tipo que todos temos visto dezenas de vezes, nas tardes de domingo, no decorrer das festas populares, e que, depois de dormir e vomitar na sargeta ou na estrada, acorda pedindo água.

Um pouco acima está Estéfano, o cantineiro do navio d' "A Tempestade". O navio naufragou; Estéfano e o bufão Trínculo vieram aportar a uma ilha quasi deserta, pois nela vivem apénas três pessoas: Próspero, antigo duque, ali exilado; Miranda, sua filha, e Caliban, um escravo disforme e descontente. Convém saber, para melhor entendimento dos fatos, que tambem escapou do naufrágio uma provisão de vinho. Quando Estéfano se apresenta em cena, com uma garrafa na mãe, e a cantar canções eróticas, já traz a sua modesta inteligência e o seu fraco poder de critica visivelmente prejudicados pelo álcool. Acolhe, pois, sem maior exame, a proposta de Caliban, o rebelado: Estéfano matará Próspero, apoderar-se-á de sua filha Miranda, ficará rei da ilha.

Rei de uma ilha deserta! Ser rei de alguma coisa era seguramente a obtusa ambição que dormitava sob cinzas, no intimo de Estéfano. Continham-lhe o ímpeto, mal pressentido por êle próprio, a ausência de oportunidade e a repressão social. Veiu a ilha, veiu o álcool, e a ambição flamejou, espevitada por Caliban. Estéfano será rei; Miranda será rainha; Trínculo terá o título de vice-rei; Caliban o de logar-tenente.

Um candidato a rei dorme, efetivamente, dentro de cada um de nós: rei de ilhas desertas ou de continentes saturados de população; rei de barulhentos feitos esportivos ou de intermináveis romances de amor; rei na arte ou rei na ciência; rei na felicidade ou na glória. Todos aspiram a 
desprender-se dos empecilhos que lhes atravancam a vida, e, sobrepairando acima das restrições naturais ou sociais, salientar-se, possuir, dominar. A inteligência e a cultura de cada um escolhe o território do reino e risca-lhe as fronteiras. Venha a ilha deserta, atue o álcool, e o candidato abrirá ao sol as páginas da sua proclamação.

Pistol é um espadachim tagarela e fanfarrão do bando de Falstaff. Foi bem caracierizado nestas palavras do pagem que o acompanhou à guerra na França:

"uma lingua mortifera, uma espada tranquila".

Que é que produz nele a embriaguez? O afrouxamento das inhibições, fracas por natureza, do seu estado de sobriedade. Pistol se torna então ainda mais palrador, ainda mais fanfarrão. O palrador estropia versos das comédias que ouviu; confunde "Annibal" com "Canibal"; fala nos "troianos gregos", cita entidades mitológicas, diz frases em línguas extrangeiras que ignora. O fanfarrão insulta uma rapariga e discute vivamente com Bardolfo; puxando da espada, ameaça praticar "incisões", antevê sangue derramado; mas não vai além. A coragem de lutar não existe, o álcool não lh'a dá. Por isso, Pistol cede ao menos belicoso porém mais inteligente da companhia, ao pusilânime Falstaff, que calculadamente desembainha a espada e convida o brigão a retirar-se. E é Falstaff quem, afinal, paradoxalmente, ganha fóros de valente perante a rapariga da taverna: Doll Tearsheat o proclama

\section{"tão corajoso quanto Heitor, tão valente quanto cinco Agamenons".}

(2 Henrique IV. II, iv)

Agora um exemplar de borracho alegre e de boa companhia: o cavalheiro Tobias, de "Véspera de Reis" Para Marshall, "Tobias é o tipo imortal do "engraçado" mediocre, do bom companheiro dos clubes e casas de bebidas. Vêmo-lo diariamente na rua, gorducho, de cara redonda e 
rosada, com um par de olhos a sorrir para a interminavel pilhéria que é a vida" (40). Num temperamento destes a embriaguez não traz sinão a alegria, o ruido, e, no fim, o sono. Tobias, à moda de certos inveterados de clubes, pélase por uma "boa peça", em que os espertos cáiam como "patinhos" Tobias canta em côro com os foliões amigos. Tobias arrisca, com as mulheres, uma ou outra palavra equívoca, mas não prossegue. $E$ si chega a bater-se em duelo, em que é ferido de verdade, Tobias não o faz sinão por engano: saiu-lhe um dia "o trunfo às avessas"

\section{A EMbriagulez de CÁSSIO}

A embriaguez de Miguel Cássio, no segundo ato de "Otelo", apresenta duplo interêsse. Em primeiro logar, do ponto de vista dramático, esta embriaguez não constitue, como as outras, episódio acessório, e sim um incidente capital, no desenrolar dos acontecimentos. Em segundo logar, e agora sob o aspecto psico-patológico, o fenômeno, tal como nô-lo exibe Shakespeare, é um verdadeiro modelo de demonstração teatral do etilismo agudo. Seja a sua concepção o resultado de estudos meticulosos, seja o produto de uma intuição genial, o fato é que ela exprime, dentro da veracidade científica, um caso perfeitamente didático e "real" de evolução da embriaguez alcoólica.

E' mister conhecer de antemão a personalidade de Cássio. A figura deste personagem não apresenta relevos excepcionais; dir-se-ia, em linguažem corrente, que Cássio “é um homem como os outros": bon carater, honesto, dedicado; alem disso, corajoso e combativo, tanto quanto devem ser os soldados. Não possue, todavia, a têmpera muito sólida, e, por isso, na falta de poderes de resistência interna mais robustos, Cássio se subordina principalmente à opinião alheia, à "reputação": quer "ser", mas sobretudido quer

(40) Inving e Marshall - op. cit. IV, 358. 
"parecer" bom; quer que o tenham como bem educado, quer sentir o aplauso alheio.

A preocupação de Cássio, de atender à opinião, - verniz social aliás correntio e certamente útil na vida coletiva, - aparece acentuado muito de leve pelo poeta. Ao receber, no desembarcadouro, Desdêmona, Iago e Emília, Cássio beija esta última. Mas explica-se logo com o marido e chama a atenção para a sua própria educação e cortezia:

$$
\begin{aligned}
& \text { ¿não vos aborreça, bom Iago, } \\
& \text { Que eu exiba êstes modos; é a minha educação } \\
& \text { Que me ordena êste gesto de ousada cortezia". }
\end{aligned}
$$

(Otelo, II, i)

Outra prova. Cássio, que é solteiro e livre, encontra-se com Branca, sua amante, corteja-a, diz-lhe repetidas palavras de amor. Mas como Otelo se aproxima, Cássio trata de distanciar a mulher, para que o general não pense mal dele:

"Não tenho interesse nem desejo
Que êle me veja com uma mulher".

(Otelo, III, iv)

Não o condenemos por isso. Mas êsse meticuloso respeito à sanção social, indício de desconfiança de si mesmo, tem, em Cássio, um fundo sub-concientemente interesseiro: Cássio quer "fazer carreira" (II, iii), e sabe que a "carreira" depende não só dos méritos do indivíduo como, especialmente, do reconhecimento desses méritos por outrem:

"Estando eu ausente e meu logar preenchido,
o general esquecerá minha dedicação e serviços". (III, iii)

Ponto de vista, por certo, infinitamente mais moral que o de Iago, para quem o suficiente é "parecer".

Para conciliar em seu favor a ambicionada "opinião", Cássio não se cança de louvar o general; louvor sincero, é 
verdade, sem nenhum intúito conciente de bajulação; mas inspirado, obscuramente, pelo desejo de publicar o seu apêgo ao chefe, tendo em vista vantagens egoísticas.

Mesmo o valor de Cássio em face do perigo físico, tem limites, pois é grande a amor que êle vota ao seu próprio corpo. Depois de reagir ao ataque de Rodrigo, no quinto ato, e ferí-lo, êle é, por sua vez, ferido na perna por Iago. Os seus gritos, então, não parecem os de um soldado destemido:

\author{
"Estou estropiado para sempre! Socorro! Um \\ assassino!" \\ "Socorro! Tragam luz! Um cirurgião!" \\ "Onde estão os guardas?" \\ "Cuidem de mim!"
}

Otelo, em situação análoga, não teria gritado; ou, si o tivesse feito, seria de outro modo.

Em suma, o Cássio social, o Cássio sem álcool, é um exemplar humano bastante corriqueiro, e comporta esquematicamente três camadas psicológicas sobrepostas. Na mais superficial estão as inibições, que o fazem discreto, ponderado, preocupado com a sua "carreira", cioso (mas sem exagêro notavel) da sua reputação; na camada intermediária se comprimem a parlapatice vulgar, os informes desejos de alçar-se até ao general, a agressividade grosseira; na camada profunda jaz o amor animal à pele, germe da sua instintiva pusilanimidade. A embriaguez, tal seja o seu grau, pode atingir mais ou menos intensamente a primeira camada; a emoção, si muito violenta, pode ultrapassar a segunda e chegar-lhe ao ámago do psiquismo.

Mas vamos ao caso da embriaguez.

Iago resolveu desacreditar Cássio perante Otelo e os moradores da ilha. Arquitetou, para isso, um plano malignamente ardiloso: vai embebedar Cássio, tornando-o, assim, irritavel e bulhento; vai pô-lo entre convivas igualmente embriagados; vai, finalmente, lançar contra êle um suposto rival, Rodrigo, por sua vez perturbado peìo álcool: 
"Nesse bando de bêbados, Vou levar Cássio a algum ato Que ofenda a ilha"

A vítima resiste à maliciosa pressão de Iago, porque se supóe extremamente fraca para o vinho: vinho".

"Tenho uma cabeça fraca e desageitada para o

Considera-se mesmo um doente e um infeliz por isso:

" $\hat{E}$ uma enfermidade que me infelicita"

Não devemos, porém, levar muito a sério esta suspeita. Cássio não apresenta nenhuma das causas que possam justificar a alegada sensibilidade doentia em relação ao álcool: nem epilepsia, nem histeria, nem traumatismo craniano, nem emotividade excessiva, nem depressão nervosa. O seu caso é pura e simplesmente o dos individuos sóbrios, cujo organismo oxida com lentidão o álcool. Daqui a pouco irá ĉle prová-lo, não apenas pela ingestão de quantidade bastante alta de vinho, como ainda patenteando manifestações etílicas inteiramente típicas.

A recusa de Cássio esmorece depressa. Convidou-o Iago no melhor momento, quando o seu poder de resistência já estava diminuido pelo próprio álcool:

“Bebi apenas uma taça, esta noite, - e cuidadosamente diluida, - mas veja que perturbação me produzio".

Além disso, Iago usou de dois ótimos pretextos: o de atender a um grupo de amigos que estavam à porta, e o de beber à saude do general. Como se animaria a recusá-lo quem vivia preocupado com a opinião social? como fugir quem se sentia no dever de multiplicar as provas de defe- 
rência para com Otelo? Cássio diz, pois, como é frequente ainda hoje, entre convidados indecisos:

"Eu aceito, embora isso me contrarie".

E sáe da cena, para ir dobrar-se ao irresistivel apêlo social. Dai a pouco, quando volta, já acrescentou à taça de que se queixara, cêrca de meio litro de vinho. Era o suficiente para a sua sensibilidade de temperante. Iago, porém, não está satisfeito e insiste:

“Mais vinho, rapazes!”

A embriaguez vai então progredindo, na medida da absorção do álcool e da sua chegada ao cérebro. $O$ sizudo soldado começa a interessar-se pelas canções brejeiras de Iago; maravilha-se depois ante as proezas báquicas dos inglêses. Entrementes, vai bebendo mais:

“A saude do general!”

Como cresce a concentração alcoólica do cérebro, tambem se agrava a perturbação da conduta. A casca psicológica das inibições está sofrendo rápida dissolução; Cássio solta a lingua, revela confusas ambições, diz coisas puerís e sem nexo:

Cássio - Bem. Deus acima de tudo; e há almas que devem ser salvas, e há almas que não devem ser salvas.

Iago - Isso é verdade, bom tenente.

Cássio - Pela minha parte, - com perdão do general e de todos os homens de qualidade. espero ser salvo.

Iago - E eu tambem.

Cássio - Sim, mas com vossa licença, não antes de mim; o tenente deve ser salvo antes do alferes. Mas deixemos isso: vamos ao que nos interessa. Que Deus esqueça os nossos pecados. Ca- 
valheiros, vamos ao serviço. Não penseis, cavalheiros, que eu esteja bêbado; êste é o meu alferes; esta é a minha mão direita; está é a esquerda. Não estou bêbado neste momento; posso ficar em pé muito bem; posso falar muito bem.

Exuberância verbal, expressando um pensamento mais ou menos descosido; preocupações infantís de precedência hierárquica; atenção atraida para um equilíbrio e uma articulação verbal que se estão dificultando cada vez mais, tudo indica que Cássio entrou no segundo periodo da embriaguez, no período de confusão e de ataxia inicial; de uma embriaguez por enquanto otimista, palradora e presumida. Uma palavra menos cortez, uma provocação bastará agora para desaçaimar a agressividade do soldado e para impelílo à prática desmoralizante que Iago tanto ambiciona.

E' o que vai suceder, levando a intoxicação ao acme das suas reações. Ao sair, Cássio encontra Rodrigo, e êste, propositadamente, o adverte com grosseria. Cássio persegue Rodrigo até à cena, insulta-o, agride-o. Intervem Montano, um dos convivas da ilha; mas, como tambem se acha excitado pela álcool e já tem o espírito prevenido contra Cássio, começa segurando a êste e chamando-o bêbado. Cássio, enfurecido e desgovernado, ataca tambem Montano e o fere gravemente. Ao mesmo tempo, por manobra de Iago, os sinos tocam a rebate, a cidade desperta, o general acorre. Iago conseguira o que queria: escandalizar a população, desmoralizar Cássio perante Otelo.

Principia então o desanuviamento, a curva descendente da perturbação alcoólica. No primeiro momento após a chegada de Otelo, Cássio ainda não se sente muito seguro de si:

\section{"Queira perdoar-me: não posso falar".}

Logo a seguir, porém, sòsinho na presença de Iago, já se domina e percebe claramente a enormidade do seu desatino. Refaz-se quasi de súbito o verniz das inibiçôes so- 
ciais, mas, por um resto ainda de depressão alcoólica, a preocupação dominante se reveste de aspeto caricato:

Cássio - Reputação, reputação, reputação! Oh,! eu perdi minha reputação! Perdi a parte imortal de mim mesmo, e o que me resta é bestial. Minha reputação, Iago, minha reputação!

Iago - Palavra de honra, pensei que tinheis recebido alguma ferida corporal; há mais prejuizo nisso do que na reputação. A reputação é um atributo vão e dos mais mentirosos, frequentemente alcançado sem mérito ou perdido sem desmerecimento; não perdestes nenhuma reputação, desde que não a considereis perdida.

A desintoxicação se opera em ritmo acelerado. Cássio já reconhece, nítida, a situação e comenta com superioridade os maleficios do álcool. O proprio Iago se surprende da rapidez desta metamorfose:

"Oh! mas estais inteiramente bom: como recuperastes assim vossa serenidade?"

A ação curativa da supreza sobre os fenômenos da intoxicação etílica não é fantasia do poeta: "Nada desembriaga um homem tão rapidamente (dizem Carter e SouthgaTE), depois de um acidente de veículo, como o fato de se achar na polícia, com a certeza de um julgamento no dia seguinte. Nós nos temos muitas vezes impressionado com êsse poder de reconquistar o governo de si proprio" (41). O duelo, o alarma, a chegada de Otelo, a sua destituição, eram para Cássio estímulo mais do que suficiente para mobilizar as últimas reservas de auto-governo e apressar a cura.

(41) Capter e Southgate - The Excretion of Alcohl in the Urine as a guide to alcoholic intoxication, in Transactions of the Medico-Legal Society, Cambridge, 1926, pag. 33. EBEL explica a ação desembriagadora dos estimulos emocionais pela influência da epinefrina sobre o organismo. A extirpação das suprarrenais diminue a tolerância ao álcool (Journal of Am. Med. Ass., 4 fev. 1939, 464). 
Vem por fim o interrogatório a que Iago submcte a sua vitima :

Iago - Quem era, afinal, a pessoa que perseguieis, com a espada em punho? Que vos havia ela feito?

Cássio - Não sei.

Iago - Será possivei?

Cássio - Eu me recordo de uma massa de fatos, mas nada distintamente. Lembro-me de uma briga, mas ignoro a causa.

E com êste pormenor da lembrança corıfusa e lacunosa dos fatos ocorridos durante a embriaguez - da amnésia post-alcóolica -, ShaKespeare encerra êste quadro magistral em que o penetrante poder de observação e a grande capacidade de expressão do artista dão uma das suas melhores demonstrações.

\section{JOÃO FALSTAFF, BEBEDOR HABITUAL}

Sobe finalmente ao tablado, - "the last but not the least", - João Falstaff, "a mais original e tambem a mais real de todas as creações cômicas" (42); "volumosa bombarda de vinho", que ilumina, com as cintilações do seu espírito, quatro peças do teatro shakespeareano (43).

Quanto ao físico, Falstaff é, na classificação de KrETsCHMER, uma bela figura de pícnico, uma "pipa de banha" com o seu magestoso abdome em proeminência, o queixo roliço e duplo, a cara ampla, cheia, gordurosa, emoldurada pela brancura de uma barba florescente.

Psicológicamente, enquadra-se o enxundioso cavalheiro na caracterização clictotímica do biotipologista alemão. Desde a primeira cena em que aparece, "nós nos sentimos à

(42) Irving e Marshall - op. cit., III, 335.

(43) Os dois "Henrique IV", "Henrique V" e "As Alegres Comadres de Windsor". 


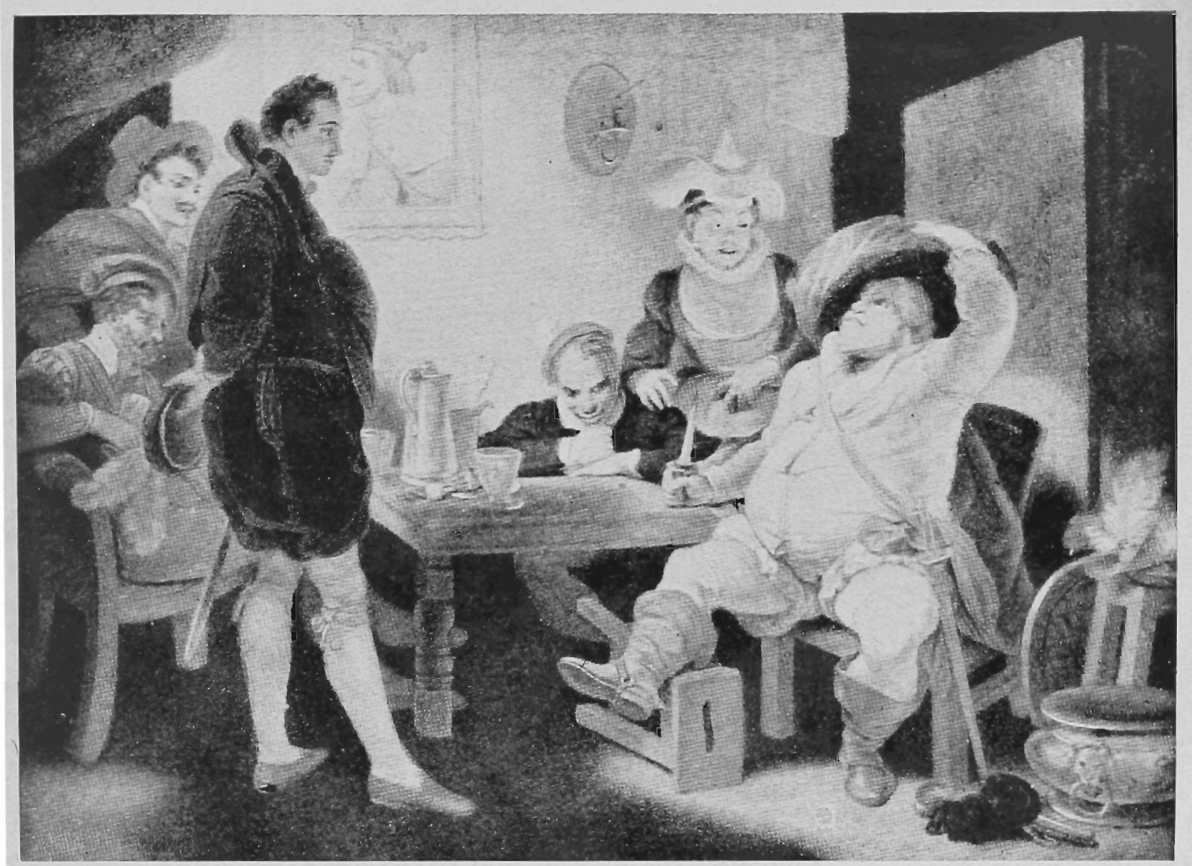

Falstaff e o seu bando de foliões (1 Henrique IV, II, iv). Reprodução de um quadro de Roberto Smirke. 
vontade com êle" (44), como si se tratasse de um velho camarada de infância. A sua presença aquece o ambiente, anima, revigora a palestra; pois, seguindo a regra dos sintônicos, Falstaff se entende com toda a gente, sabendo nivelar o seu diálogo tanto com a vulgaridade de Pistol como com a severidade do Juiz Superior ou a insolência do príncipe da coroa. Seu convívio plástico, cativante, comunicativo, alimentado por uma fertil imaginação, acomoda-o sempre bem, na taverna, ou no palácio do rei.

Falstaff é sobretudo um sensual, um gozador. Displicente em face das situações sérias, extende a mão, ávido e guloso, para as coisas boas - e faceis, - que a vida lhe possa proporcionar. Pergunta êle um dia as horas ao principe Henrique. 0 príncipe extranha e interpela-o:

"Que diabo tem você com o tempo? A não ser que as horas sejam taças de vinho, e os minutos frangos assados,. não vejo razão para que você se preocupe com coisas supérfluas, como essa de indagar as horas do dia".

(1 Henrique IV. I, ii)

A despeito dos seus sessenta janeiros e do seu vasto abdome, Falstaff não desdenha as aventuras de amor. Basta que uma mulher lhe passe ao alcance para que êle lance o anzol. Não lhe é indiferente a despejada senhora Quickly, estalajadeira da "Cabeça de Javalí" Doll Tearsheet, dama que frequenta tavernas e perfuma o sangue com vinho das Canárias, senta-se um dia sobre os joelhos de Falstaff e fazlhe tais caricias, que o príncipe Henrique julga divisar, no firmamento erótico, "uma conjunção de Venus com Saturno"

As boas noticias o exaltam e lhe infundem um otimismo infantil, rebelde à critica. Quando o informam de suposto êxito na conquista com que sitiou a honestidade das

(44) Charles KNight - op. cit., 724. 
duas esposas de Windsor, Falstaff não se contem que não exclame, dirigindo-se a si próprio: "Vamos, meu velho Jack! darei mais prazeres ao teu velho corpo do que o tenho feito até hoje" E acrescenta, desvanecido: "Bom corpo, eu te agradeço. Deixem que digam que és volumoso; contanto que sejas bem feito, pouco importa"

Mas João Falstaff não é apenas uma pipa de banha: tambem é uma rica e inexgotavel "pipa de espírito" Não há silêncio em torno dêle; vem-lhe, para tudo, a melhor réplica; os mais vulgares acontecimentos dão-lhe pretexto a comentários e reparos humorísticos. O seu espírito conserva, no entretanto, um fundo de bondade natural, que o preserva da mordacidade e o impede de lançar farpas envenenadas. A sua gorda bonhomia tudo compreende, tudo perdoa. Isento de preocupação moralizadora, não o persegue o desejo de endireitar o mundo ou de adatá-lo às suas fórmulas pessoais. Si o príncipe o houvesse chamado para inspirador do trono, Londres teria legalizado a boemia e a gatunice noturnas, pois, na expressão do cavalheiro, a cidade passaria, "como o oceano", a ser governada pela "nobre e casta dama a lua", sob cujas vistas benévolas continuariam, êle e o seu bando, a visitar as tavernas e a praticar desabusadamente as costumeiras tropelias.

A larga indulgência de Falstaff perdoa todos os pecados, a começar pelos seus :

\footnotetext{
"Eu tenho mais carne que os outros homens, e, por conseguinte, sou mais frágil”.
}

Numa criatura deste tipo não existem excessos de vaidade ou de amor próprio. Falstaff nem pavoneia os seus dons de inteligência, nem se melindra com os frequentes arranhões que sofre a sua dignidade.

Tal é, parece-nos, o fundo essencial, nativo, da psicologia de Falstaff, antes da infiltração alcoólica. Em suma, um ciclotímico inteligente, epicurista, de fraca moralidade. 
Mas Falstaff começou a beber; apegou-se ao vinho; bebe diariamente, bebe sempre que pode; tornou-se o tipo do bebedor habitual.

Por que veiu êle ao vício?

Uma força inicial, - a do seu próprio temperamento, deu o primeiro impulso. Propenso à companhia alegre, pouco apto à atividade mental sem os estímulos da convivência, Falstaff encontrou no álcool, ao mesmo tempo, pretêxto para as reuniões sociais e um agente fácil do prazer. Outra fosse a reação do ambiente, ou mais forte se erguesse a resistência interna, talvez o sensualista inteligente estacasse ou retrocedesse. Mas não retrocedeu nem estacou.

E' que a bebida lhe serviu ainda de mecanismo de compensação. $O$ álcool proporciona uma fuga pronta às situações deprimentes, e a Falstaff afligiam, além das depressões naturais do seu temperamento, os quotidianos conflitos psicológicos com o meio. As contingências o levam a viver numa sociedade intelectualmente inferior, grosseira, que o não respeita, e em cujo seio êle se atola mais e mais. Todos, desde Bardolfo até o pagem, o tratam com insolência. 0 próprio príncipe Henrique não lhe poupa remoques, e, abusando da sua realeza, humilha o companheiro com apôdos e sarcasmos:

"Homem gordo e velhu; inchado tipo de hidrópico, compadre rufião, bom só para experimentar vinho e bebê-lo; vilão em tudo; útil para coisa nenhuma"

Ao que Falstaff, como única reação possivel, responde, referindo-se a si próprio na terceira pessoa:

"Que êle é velho, seus cabelos brancos o dizem; mas que é um rufião, isso eu energicamente contesto". "Si ser velho e alegre é pecado, então muitos velhos freguezes que conheço estão condenados; e si os gordos devem ser odiados precisamos adorar as vacas magras de Faraó".

(1 Henrique IV II, iv) 
Em cada investida destas, o resto de amor próprio tem que capitular. Capitula, e vai procurar uma compensação no copo de vinho. Forma-se então um. círculo vicioso: o amor próprio ferido busca consolo no álcool; o álcool anemia ainda mais o depauperado amor próprio, abrindo ensejo a afronta maior. E assim, de agravo em libação e de libação em agravo, a dignidade desce cada dia um degrau. Falstaff, roubado, bebe; injuriado, bebe; jogado no Tâmisa com a cesta de roupa suja, bebe; espancando sob as vestes da velha feiticeira, tambem bebe.

Por fim, o último ultrage, o que mais vivamente o alanceia e para o qual não há compensação no vinho. $O$ príncipe, seu inseparável companheiro de orgias noturnas, é coroado rei da Inglaterra e assume as rédeas do poder. Ao ser informado do acontecimento, Falstaff exulta, pois vai dágora em diante compartilhar do mando, distribuir recompensa e castigos:

\footnotetext{
“As leis da Inglalerra estão à minha disposição. Felizes os que têm sido meus amigos. Ai do Juiz Superior!"
}

Toma dinheiro emprestado, monta a cavalo e, abalando as pesadas banhas, dispara pela estrada para ir ver o novo rei. Chega, e afim de que o amigo note o seu açodamento em procurá-lo, nem siquer muda de roupa, apresenta-se coberto com o pó da viagem. O joven rei entra, magestoso, e vai passando. Falstaff aproxima-se, banhado em riso e, numa alegria infantil, ameaça lançar-se aos braços do novo soberano. Mas Henrique V, encarando-o, diz-lhe friamente:

$$
\text { "Não te conheço, velho". }
$$

E afasta-se, para nunca mais avistá-lo.

Politicamente, o gesto drástico de Henrique V foi sensato: o trono da Inglaterra precisava ficar preservado da influência desmoralizante de todos os Falstaffs. Mas foi brutal. O resto de dignidade que ainda dormitava na alma do 
cavalheiro, estremece; e desde aí seu coração se abate, sem que nenhum vinho possa reanimá-lo. Falstaff definha, e afinal expira melancolicamente, em casa extranha, assistido apenas pelos rudes companheiros de folia. A estalajadeira recolhe as suas últimas palavras: uma maldição para as mulheres - ventura inatingida, causa maior das suas humilhações - e um derradeiro apêlo ao vinho, o grande consolador nas suas desditas, o seu refúgio de compensação.

Falstaff é um bebedor habitual. Afeito ao vinho, e, graças ao seu temperamento, reagindo ao álcool normalmente, suporta grandes libações sem propriamente embriagar-se e sem chegar a nenhuma forma de psicose tóxica. ShakesPEARE não o mostra nem atáxico, nem confuso; mostra-o apenas no seu estado de aparente exaltação psíquica, nesse comunicativo humorismo, dolorosamente conquistado mediante a intoxicação etílica, e no lento sossobro da sua dignidade.

Pintando homens do seu tempo, o poeta inglês "retratou tipos eternos e universais".

De fato, do ponto de vista do alcoolismo, Falstaff tem a significação de um esquema que, com variantes internas, se repete indefinidamente no tempo e no espaço. A sua trajetória, tal como tentamos descrevê-la, tem sido e será o roteiro de milhares de inteligências em que o fraco arcabouço moral se desfaz, diluido nas frouxidões do meio e nos enganosos vapores etílicos.

E si a pintura do poeta é perfeita, sua moralidade é inexorável. Falstaff, - uma pipa de vicios, — pagou na terra todos os pecados. Viveu afogando em álcool as íntimas amarguras, e extinguiu-se miseravelmente na solidão e na penúria.

\section{AS FASES DA EMBRIAGUEZ}

E' uso reconhecer "fases" na embriaguez, e não vai nisto nenhum mal. As fases carecem de limites precisos; há individuos que não lhes seguem a progressão comum; fenômenos atribuidos a uma fase às vezes se manifestam em ou- 
tra. Tudo isso é verdade, mas não inutiliza a tradicional esquematização, que permite, na maioria dos casos, exprimir sinteticamente o grau de perturbações nas reações do indivíduo embriagado.

Discriminam-se, em regra, três fases: a de excitação, a de confusão e a de sono. Certos autores admitem quatro fases; outros, cinco. Para Pessina, por exemplo, a primeira fase se dividiria em duas: uma, inicial, em que o álcool excita as atividades fisiológicas, mas não atinge o psiquismo; outra, subsequente a esta, acompanhada de leve prejuizo para as funções mentais. Niccolin adota mais ou menos a mesma divisão (45). EMIL BogEN descreve as quatro fases de Pessina, mas desdobra a última em duas partes, ficando, pois, decomposto o fenômeno em cinco tempos: o estágio sub-clínico ou de latência, o de excitação, o de confusão, o de estupor e, finalmente, o de côma, produzido por doses excessivamente altas (46).

Shakespeare é pela divisão em fases. Nesta passagem de "Otelo" acentua êle, por meio de comparações, a progressão da embriaguez:

"Estar o homem no uso da razão; um instante depois, ser um tolo; no minuto seguinte, um animal! Extranho!”

(Otelo, II, iii)

Em outra peça, "Véspera de Reis", decide-se o poeta expressamente pela discriminação tripartida. 0 cavalheiro Tobias aparece em cena visivelmente perturbado, "bêbado pela metade", como diz sua prima Olívia. Quando êle se retira, Olívia pergunta ao bobo:

Olivia - Com que se parece um bêbado, bobo?

$o$ bobo - Com um homem afogado, com um tolo e com um louco; uma dose acima do normal

(45) Luigi Lucchini - Dig. Italiano, XXIII, ii, ubbriacchezza. (46) EmIL Bogen - Human Toxicology of Alcohol, in Alcohol, and Man, 133 a 136. 
faz dele um tolo; uma segunda o enlouquece; uma terceira o afoga.

Olívia - Vai então buscar o “coroner" (47), para que se faça inquérito a respeito do meu primo; pois êle está no terceiro grau da embriaguez; está afogado: vai procurá-lo.

$O$ bobo - Elle está apenas louco, senhora; o bobo tomará conta do louco.

(Véspera de Reis, I, v)

Os casos de embriaguez da primeira fase são frequentes no teatro de Shakespeare: Cássio, no inicio da sua famosa bebedeira; os convivas de Cássio, na ilha de Chipre; Falstaff e Bardolfo, em seu estado costumeiro; os cavalheiros André e Tobias, em algumas cenas de "Véspera de Reis"

$\mathrm{Na}$ segunda fase, com as idéias confusas e o equilibrio prejudicado, apresentam-se Cássio, depois das novas doses que bebe; Pistol, na cena em que Falstaff o escorraça da taverna; Estéfano, quando se propõe conquistar o trono da ilha deserta; Caliban; Cristovam Sly, ao sair da taverna; o cavalheiro Tobias, na ocasião em que dá ao bobo de Olívia ensejo para doutrinar sobre a embriaguez.

Da terceira fase, Shakespeare dá uma descrição sumária, pela boca do cavalheiro Paroles:

“A embriaguez é a sua mais suave virtude: pois êle se embebeda como um porco; e, uma vez adormecido, não faz mal nenhum, a não ser aos lençóes que o envolvem; mas como êsses seus hábitos são conhecidos, deitam-no sobre a palha"

(Tudo está bem quando acaba bem, IV. iii)

Em "As Alegres Comadres de Windsor", Slender, dolosamente embebedado pelo bando de Falstaff, chega à fase de sono, perdendo, no dizer de Bardolfo, "suas cinco sentenças" Aproveitam-se disso Bardolfo, Nym e Pistol para

(47) O “coroner", encarregado de "negócios da coroa", procedia a inquérito para a verificação la causa da morte. 
subtrair-lhe o dinheiro que tinha consigo. Eis porque o pobre Slender fez o juramento de daí por diante só se embriagar na companhia de bêbados honestos (I. i).

Da representação concreta, em cena, desta fase terminal da bebedeira, encarrega-se o caldeireiro Cristovam Sly, de "A Megera Domada"

Finalmente, o banquete da galera de Pompeu, em "Antônio e Cleópatra", of erece-nos, contemporaneamente, as três fases do alcoolismo agudo: a primeira (embora avançada. .) em Cesar, que compartilha da excitação geral mas raciocina com clareza; a segunda, em Marco Antônio, dansando de mãos dadas com os demais, à espera da "doce letargia" produzida pelo vinho; e a terceira em Lépido, que sáe da festa carregado nas costas de um escravo.

\section{A EMBRIAGUEZ E OS ANIMAIS}

Os animais, - salvo, ao que contam, o gambá, - não se embebedam. Pouco importa: são largamente manipulados na literatura, seja para simbolizar a embriaguez em geral, seja para representar cada uma das fases do fenômeno ou, mais raramente, para significar os varios tipos de bêbados.

Da esponja, o que se aproveita na comparação é simplesmente a capacidade física de absorpção. A expressão "bêbado como uma esponja", corrente ainda hoje, não era extranha a SHaKespeare:

"Farei tudo quanto puder para não me casar com uma esponja", diz Portia, no "Mercador de Veneza", ao pensar na candidatura do moço alemão. E para "lady" Macbeth, os guardas do rei Duncan, que ela pretende adormecer pelo vinho, são "oficiais esponjas"

Os inglêses, desde, pelo menos, o século XVI, costumam dizer: "bêbado como um animal" ou "bêbado como um porco" Mas êste modo de falar, mau grado a opinião de D’Is- 
raeli (48), não é privativo deles: alemães, italianos, portuguêses empregam expressões análogas. Quanto aos francêses, preferem descontar alguma diferença com os polonêses, dizendo: "soûl comme un polonais"

Shakespeare vê no porco o símbolo da embriaguez. Parodes, personagem de "Tudo está bem quando acaba bem", ao descrever a bebedeira de um cavalheiro, diz:

“embebeda-se como um porco".

Do mesmo modo, o "lord" da Introdução de "A Megera Domada", quando vê o caldeireiro Cristovam Sly a dormir no chão, de bebedeira, exclama:

$$
\begin{aligned}
& \text { "Que animal monstruoso! Ei-lo a chafurdar } \\
& \text { como um porco". }
\end{aligned}
$$

E Hamlet, referindo-se aos hábitos de embriaguez de seu povo, comenta:

"As outras nações nos caluniam, chamando-nos bêbados e acrescentando ainda: $\operatorname{porcos"~(I~iv).~}$

Da simbolização das fases da embriaguez por diferentes animais, à moda da lenda árabe do macaco, do leão e do porco, não encontramos exemplo em Shakespeare. Para êle, segundo vimos, na primeira fase o homem é tolo, na segunda é louco, e na terceira parece um afogado. Tambem não vimos recurso à zologia (salvo o caso do porco) para a fi-

(48) D'IsRaeli — op. cit., 258: “Quando a embriaguez se tornou pela primeira vez comum em nosso paiz, durante o reino de Elizabeth, era ideia dominante entre os escritores do tempo, -ideia sobre a qual exercitaram a sua imaginação, - que o individuo, nas diferentes fases da embriaguez, mostra as piores qualidades dos animais". E a propósito cita Georges Gascoigne, de 1576: “Todos os bêbados são animais" Para o autor. esta aproximação seria só dos escritores inglêses. 
guração das variantes individuais nas manifestações da bebedeira (49).

\section{EFEITOS PARTICULARES DO ALCOOLISMO AGUDO}

Antes do periodo rigorosamente objetivo, inaugurado recentemente pela ciência, os médicos, os filósofos e os escritores literários já haviam reunido uma farta messe de observações sobre os efeitos físio e psico-patológicos do álcool. Como já acentuamos em outro trabalho, muitos desses efeitos estão sendo integralmente confirmados pelas observações e pelo laboratório (50).

ShaKespeare registrou em sua obra principalmente os fenômenos grosseiros determinados pelo uso das bebidas, os fenômenos que o vulgo observa, comenta e incorpora na chamada sabedoria popular. Não esqueceu, porém, alguns fatos menos patentes, de verificação mais sutíl. Vamos à demonstração.

O álcool avermelha os olhos, dando a impressão de que choraram. O príncipe Henrique sugere a Falstaff que o repreenda, como si Falstaff fosse o próprio rei. Antes de desempenhar o seu papel, o improvisado pai reclama uma taça de vinho:

"que torne os meus olhos vermelhos, para que se pense que chorei, pois devo falar apaixonadamente" (I Henrique IV, II, iv)

$\mathrm{E}^{\prime}$ indiscutivel que o álcool dá a sensação de calor. $\mathrm{E}^{\prime}$ discutivel que aumente de fato a temperatura do corpo.

(49) D'Israeli (op. cit.) menciona a seguinte classificação preconizada por um autor contemporâneo de SHAKESPEARE: 1) bêbado-macaco, o que dansa, grita e canta; 2) bêbado-leão, o que insulta e briga; 3) bêbado-suino, o que dorme; 4) bêbado-carneiro, o discreto, silencioso; 5) bêbado-madalena, o que chora apaixonado e diz, beijando o companheiro: "eu gosto de você, capitão"; 6) bêbado-lontra, bebe sem se mexer; 7) bêbado-bode, que não cuida sinão de atos libidinosos; 8) bêbado-raposa, que só faz negócios quando está embriagado.

(50) A. Almeida Júnion - art. cit. Rev. Fac. Dir. 
Shakespeare segue a opinião mais corrente, a única em vigor na sua época: o álcool não só produz sensação de aquecimento, como realmente aquece (51). O picador do "lord", na Introdução de "A Megera Domada" assim se exprime, a propósito de Sly, que jaz na porta da taverna:

"Si êle não estivesse aquecido pela cerveja, êsse leito seria muito frio para que pudesse dormir profundamente"

O vinho, - já o disse, de cảtedra, a estalajadeira da "Cabeça de Javalí" - penetra no sangue para perfumá-lo. Mas tambem para aquecê-lo. O Aquiles shakespeareano, na véspera do combate com Heitor, declara, a propósito deste seu inimigo, que êle pretende obsequiar:

“Aquecerei seu sangue, esta noite, com vinho grego, Para esfriá-lo amanhã com a minha cimitarra"

(Troilus e Cressida, V, i)

O álcool aquece particularmente o fígado. Fígado quente é sinônimo de embriaguez. Bardolfo, exibindo a face rubra e fazendo sentir as exalações do pulmão, pergunta ao príncipe Henrique o significado desses fenômenos.

"Figado quente e bolsa fria",

(1 Henrique IV. II, iv).

responde o príncipe.

E Charmion, dama de companhia de Cleópatra, gostaria de

"aquecer o fígado com bebidas".

(Antônio e Cleónatra, I, ii)

(51) Negando o aquecimento efetivo pelo álcool, v. Alcohol and Man, 1936, Nouveau Traité de Médecine (Roger, Widal, Teissier), VI, 268; Palmieri, L’Alcoolisme come Problema Medico-legale, 1933, 32, 54, 84. Admitindo a ação do álcool na defesa contra o frio, v. G. DI Macco, Alcoolismo e Assideramento, Arch. Antrop. Crim. Psich. Med. Leg., II, março-abril 1936. 
Aliás, o calor do fígado tem um sentido translato tambem, porque na época shakespeareana êsse órgão era séde da coragem e do amor, ambos susceptiveis de exaltação pelo álcool.

Ao ouvir a serena e sensata argumentação de Heitor, em Troia, em favor da entrega de Helena aos gregos, para que a guerra cesse, o fogoso Troilus adverte:

$$
\text { “a razão e o respeito }
$$

Tornam o fígado pálido e desalojam a coragem". (Troilus e Cressida, II ii)

E Bassânio, no "Mercador de Veneza", comenta:

$$
\begin{aligned}
& \text { "Quantos poltrões, cujos corações são tão falsos } \\
& \text { Como escadas de areia, usam ainda na face } \\
& \text { As barbas de Hércules e a carranca de Marte; } \\
& \text { E que, vistos por dentro, têm fígados brancos como } \\
& \text { (Mercador de Veneza, III, ii) }
\end{aligned}
$$

Em "A Tempestade", Próspero concede sua filha Miranda a Fernando, mas pede a êste que, por enquanto, seja moderado nas carícias. Responde o nôivo:

"Eu o prometo, senhor.

A branca, fria, virginal neve, sobre meu coração, Domina o ardor do meu fígado"

(A Teinpestade, IV. l)

O próprio Falstaff estaria com "o fígado a escaldar de amor" pela senhora Ford, si merecesse crédito a delação de Pistol (Aleg. Com., II 1).

O duque de "Véspera de Reis", apaixonado por Olívia, vem a saber que esta formosa dama guardará por longo tempo o luto do irmão. Expande-se, então, esperançado:

"Como será forte o seu amor, quando a seta dourada Tiver aniquilado todas as outras afeições Que vivem nela! Quando o fígado, o cérebro e o [coração, 
Esses tronos soberanos, estiverem ocupados e plenos

- Suaves perfeições. - por um só rei! (Véspera de Reis, $1, i$ )

O mesmo duque, comparando o seu amor por Olívia ao amor das mulheres em geral, diz:

"Ah! o seu amor pode ser chamado desejo, Não é impulso do fígado e sim do paladar".

(Idem, II, iv)

E' o frade de "Muito Ruido por Nada" confirma a opinião geral, sobre a séde do amor, dizendo, a propósito de Cláudio:

"Si jamais o amor interessou seu fígado.

(Muito Ruicio por Nada, IV, l)

O aumento da secreção urinária foi anotado pelo porteiro de Macbeth, que parece ter observações profundas na matéria:

A bebida (diz êle) é um grande provocador de três coisas: o rubor do nariz, o sono e a urina"

(Macbeth, II, iii)

A mesma autoridade assinala o esvasiamento do estômago através do esôfago (Macbeth, II iii), o que é igualmente observado por Titus Andronicus:

"Mas como um bêbado devo vomitá-los" (Titus Andronicus, $I I I, i)$

Ainda o porteiro de Macbeth sabe das alterações de equilíbrio acarretadas pelo álcool: justamente na véspera da sua preleção, lutou corpo a corpo com o vinho, e, segundo lealmente confessa, o adversário o pòs de pernas para o ar (II, iii). Cressida confirma a observação, quando diz:

Ajax é um homem "que sabe manter-se sósinho" porque "não está embriagado, nem doente, nem é aleijado das pernas".

(Troilus e Cressida, I, ii) 
Da disartria etílica dão-nos notícia Cássio, de "Otelo", e Cesar. O primeiro, para demonstrar que não está bêbado, afirma: "Posso falar bem". Cesar, depois de esvasiar algurnas taças de vinho, na festa de Pompeu, observa com pezar:

"minha própria língua entrecorta o que diz".

(Antonio e Cleópatra, II, vii)

Quanto aos efeitos psíquicos do álcool, alem de representá-los diretamente com os seus personagens embriagados, Sirakespeare discrimina algumas perturbações, no decorrer das suas peças.

$O$ vinho é, de modo geral, um perturbador do cérebro:

Antônio - Toquemos as nossas taças! A saude de Cesar!

Cesar - Eu dispensaria o brinde. É um trabalho monstruoso, lavar o cérebro para torná-lo mais turvo.

(Antônio e Cleópatra, II, vii)

Há no vinho uma força socializadora, que aquece o gelo das reuniões, une os homens uns aos outros, estabelece entre êles - especialmente entre os iguais no vício, - um liame de simpatia:

"Um bêbado ama outro bêbado como êle". (Trabalho de Amor Perdido, IV. iii)

Por outro lado, a embriaguez desperta as suscetibilidades: uma palavra, um gesto que os contrariem, fazem de certos bêbados térriveis criminosos. Para levar Cássio a promover questões e a bater-se em duelo, Iago estuda ardilosamente o melhor recurso:

“- Si eu puder obrigá-lo a apenas um copo de

Com o que já bebeu esta noite,

[vinho,

Ele se tornará tão propenso a querelas e ofensas

Como o cão de minha joven senhora".

(Otelo, II iii) 
O vinho adormece as inibições da língua e da discreção. "Em teus alegres transportes, ó Baco, o homem prudente deixa que lhe arranquem o seu segredo" (Horácio). De fato, ninguem tão amigo de abrir-se em confidências como o homem envenenado pelo álcool. Já se tem mesmo preconizado o seu emprego como "sôro da verdade" (52). Borachio personagem de "Muito Ruido por Nada", diz a Conrado:

"Vem cá, em baixo deste alpendre, pois está chuviscando; e eu, como um verdadeiro bêbado, te revelarei tudo".

(Muito Ruido por Nada, III, iii)

O afrouxamento da auto-crítica, determinado pelas doses iniciais de álcool, solta não só a língua como ainda a imaginação e audácia, produzindo no poeta, no escritor, no simples conversador de club, a impressão falaz de estímulo mental. "O vinho é o ginete dos poetas", dos poetas que sem êste falso excitante seriam os primeiros a condenar as suas próprias produções. Falstaff admite a ação inspiradora do vinho. Para êle,

"Um bom vinho de Xerez encerra duas propriedades. Em primeiro logar, sobe ao cérebro, e aí seca todos os vapores crus, espessos ou tolos que o envolvem; torna a concepção viva, ágil, fornecelhe torneios inesperados, animados, encantadores, que, comunicados à voz, se exteriorizam, por intermédio da língua, em palavras de fino espírito"

Em segundo logar - sempre na opinião de Falstaff — a coragem se estimula, porquanto:

“os espíritos vitais e outros habitantes menos conspícuos do interior das terras, vêm em grande número lançar-se junto do seu capitão, o coração, que, orgulhoso e dilatado por esta comitiva numerosa,

(52) Emilio Mira Lopes - Psicologia Juridica, Barcelona, 1932 , 131. Ver um caso da nossa história, no trabalho que publicamos na Rev. da Fac. Dir. S. Paulo, n. cit. 
executa tudo quanto se queira em matéria de açôes de coragem; e todo êsse valor vem do Xerez; de modo que a maior ciência nas armas de nada vale sem o vinho de Espanha"

O vinho, em verdade (Falstaff o reconhece), não creou nada, nem a imaginação nem a coragem: apenas imobilizou as forças de repressão e crítica, "os vapores crus, espessos ou tolos" que envolvem o cérebro:

"O maior saber não é sinão um tesouro guardado pelo diabo, até que o vinho de Espanha o tire da inação, pondo-o em evidência e em uso". (2 Henrique IV. IV. iii)

A amnésia alcoólica não escapara a ShaKespeare: o bêbado não registra na memória, ou registra confusamente, o que fez ou viu durante a embriaguez. Da importância desse fato na prova testemunhal, já tinha noção muito clara "lady" Macbeth, quando pretendia embriagar os guardas do rei Duncan, para poder assassiná-lo impunemente:

"com vinho e cerveja hei de dominá-los, de sorte que a memoria, sentinela do cerebro, será fumo.

\section{(Macbeth, I, vii)}

Slender é embriagado na taverna, por Bardolfo, Nym e Pistol, os quais em seguida lhe esvasiam os bolsos. No in. terrogatório, a pobre vitima não pode prestar um depoimento útil:

"Não posso me lembrar (diz êle) do que fiz depois que me embriagastes".

Não o pode, porque, na expressão de Bardolfo, êle havia bebido tanto que perdera

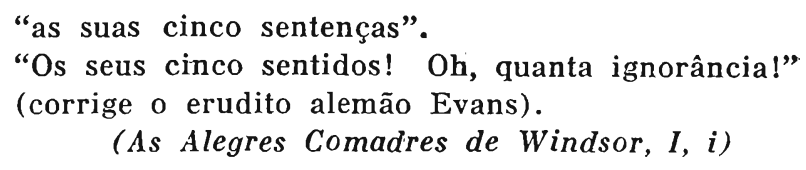


Si Lúcio, de "Pena de Talião", fosse autoridade digna de conceito, a amnésia poderia ir mais longe ainda. Eis o diálogo:

$$
\begin{aligned}
& \text { Maria - Confesso, senhor, que nunca fui casada; } \\
& \text { E confesso tambem que não sou virgem: } \\
& \text { Conheci meu marido, embora meu marido } \\
& \text { [não sáiba } \\
& \text { Que já me conheceu. } \\
& \text { Lúcio - Ele estava bêbado, então, senhor; não } \\
& \text { pode ser de outra forma. }
\end{aligned}
$$

Mas Lúcio é um libertino, e, além disso, mentiroso.

Da amnésia de Cássio, já dissemos o que era preciso, em capitulo anterior. No parecer deste mesmo Cássio, o vinho rouba a razão:

"Oh! porque introduz o homem em sua boca um inimigo que lhe rouba a razão?

$$
\text { (Otelo, II, iii) }
$$

\title{
EMBRIAGUEZ E ATIVIDADE SEXUAL
}

ShaKespeare considera o prazer do amor superior ao da bebida:

\author{
"Em confronto com o amor, o guloso Baco \\ tem o paladar grosseiro". \\ (Trabalho de Amor Perdido, IV. iii)
}

O álcool, que, na psico-fisiologia shakespeareana, eleva a temperatura do fígado, séde do amor, tambem aquece o erotismo. Mas a exaltação por êle produzida é sómente psiquica: a capacidade fisiológica correspondente sofre, ao contrário, depressão. Falando da bebida e do amor, Montaigne já advertira: “Ce sont deux occupations qui s'entre empeschent en leur vigueur" (53). O porteiro de Macbeth conhece tudo isso minuciosamente:

(53) Montaigne - Essais, II, ii. 
"Quanto à libidinagem, senhor, o vinho a provoca e a desprovoca; provoca o desejo mas impede a execução; por conseguinte, o vinho em demasia pode ser consicierado enganoso quanto à libidinagem: êle a produz e a aniquila; impele-a para a frente e puxa-a para traz; estimula-a e desanima-a; mantem-na e não a mantem; em conclusão, êle a adormece à custa de enganos e, com o lôgro, a abandona"

$$
\text { (Macbeth, II, iii) }
$$

No velho problema da fecundação durante a embriaguez, Shakespeare toca apenas de leve. Platão recomendara a abstenção do álcool antes do convivio matrimonial: os homens "não devem gerar filhos quando seu corpo se acha alterado pela intoxicação", pois o bêbado "ao que parece, produz descendentes irresolutos e falsos" (54) Nym, companheiro de Falstaff, está com Platão quando diz:

"Ele foi gerado durante a embriaguez". E acrescenta: "sua alma não é heróica".

(As Alegres Comadres de Wind'sor, I, iii)

Sessenta e poucos anos mais tarde (1668), MoLIÈRE porá na boca de Sósia, em "Anfitrião":

"Les médecins disent, quand on est ivre, Que de sa femme en se doit abstenir, Et que dans cet état il ne peuvent provenir Que des enfants pesants et qui ne sauraient vivre".

Diga-se, de passagem, que a "suposição" de Platão a "certeza" dos médicos do templo de ShaKespeare e de MolièRE, mantida ainda hoje por muitos colegas seus, é posta em dúvida pelos biologistas modernos. Mas não é aqui logar para se discutir o assunto.

Hipócrates atribuia o sexo dos filhos a o predominio da substância fecundante produzida respectivamente pelo ma-

(54) Platão - Leis, VI, trad. ingl. de B. Joivett, V, 157. Bacon registra a crença popular do seu tempo, segundo a qual "os que vão bebados para o leito geram filhas" (Sylva Sylvarum, 723). 
rido ou pela mulher. Demais, o regime alimentar teria influência sobre o vigor dessa substância: "si se quizer produzir uma filha, é preciso usar o regime aquoso; si um rapaz, o regime igneo" (55). Falstaff leu Hipócrates e aprendeu a lição. Eis o que êle diz do príncipe João, que parece não gostar do nosso cavalheiro:

"Ninguem o faz sorrir; mas isso não é de extranhar: êle não bebe vinho. Nenhum desses graves rapazes dará coisa que preste; pois sua aguada bebida lhes resfria de tal modo o sangue que (ainda por causa de suas refeições de peixe), êles caem em uma espécie de clorose masculina, e, quando se casam, não produzem sinão mulheres"

(2 Henrique IV, Iv, iii)

\section{OS EFEITOS DO ALCOOLISMO CRóNICO}

Não ficam em olvido, no teatro de Shakespeare, as consequências do uso habitual do álcool, do "alcoolismo crónico" da terminologia moderna. O quadro está longe de ser completo; mas contem, ainda assim, algumas referências dignas de interêsse.

A vermelhidão do nariz é, para Shakespeare, o sinal mais espetacular do vicio etílico. Notara-o, de passagem, o porteiro de Macbeth que, como se viu, conhece a fundo a fisio-patologia do álcool. Mas é Bardolfo quem na verdade ostenta a pirâmide nasal mais demonstrativa do fenômeno. Desse nariz incandescente, dizia Falstaff que era um "fogo fátuo", uma pira sempre ardente; e que nos passeios noturnos do bando, em Londres, a sua luz lhe economizara tochas e archotes. Contudo - advertia Falstaff — para alimentar de fogo a salamandra que era Badolfo, foram gastas incomensuráveis quantidades de vinho espanhol; de sorte que teria ficado mais em conta comprar candeias, ainda que por

(55) Hipócrates - Da Geração; do Regime, in Obras Completas, trad. E. LitTré, Paris, 1893. 
preços carissimos (1 Henrique IV, III iii). Em virtude da presença daquela proeminência abrasadora, a face de Bardolfo seria "a cosinha privada de Satanaz", onde o principe das trevas assaria todos os bebedores de cerveja (2 Henrique IV. II, iv).

$O$ joven pagem da turma de foliões, ao vir contar que o seu patrão Falstaff está sendo invadido pelo frio da morte, implora de Bardolfo:

\section{"Bom Bardolfo, coloca o teu nariz entre os seus lençóes e faze o papel de botija quente". \\ (Henrique $V, I I, i)$}

E quando Bardolfo termina os seus dias, supliciado por haver roubado uma alfáia de igreja, comunicam ao rei que:

$$
\begin{array}{r}
\text { "seu nariz foi executado, seu fogo se extinguiu". } \\
\text { (Henrique V, III, vi) }
\end{array}
$$

Os hábitos etílicos da mocidade repercutem desfavoravelmente na velhice. $O$ antigo servo de Orlando, que quer ser ainda eficiente junto ao amo, diz a êste:

$$
\begin{gathered}
\text { "Conquanto eu pareça velho, ainda sou rijo e } \\
\text { [robusto; } \\
\text { Pois durante minha juventude nunca introduzi } \\
\text { Ardentes e perturbadores licores em meu sangue". } \\
\text { (Como quizerdes, II, iii) }
\end{gathered}
$$

E ao cavalheiro Tobias, de "Véspera de Reis", Maria, dama de Olivia, adverte prudentemente:

$$
\begin{aligned}
& \text { "Essas saudes e essas bebidas serão a vossa } \\
& \text { perda". } \\
& \text { (Véspera de Reis, I, iii) }
\end{aligned}
$$

Tambem a memória acaba prejudicada pela reiteração da embriaguez. Dí-lo o principe Henrique, quando, dirigindo-se a Falstaff, exclama: 


\begin{abstract}
Estás tão embrutecido pelo uso do vinho... que esqueces de perguntar aquilo que realmente queres saber."

(1 Henrique IV, I, ii)
\end{abstract}

Da progressiva decadência moral consequente ao alcoolismo crónico, o poeta nada diz. Mas a apresentação de Falstaff e do seu bando, vivendo, sob os nosso olhos, uma vida de verdadeira abjeção e decaindo dia a dia, fala mais eloquentemente do que quaisquer palavras.

\title{
A EMBRIAGUEZ E O CRIME
}

Por adormecer a vigilância da própria vítima, ou dos que estão encarregados de guardá-la, o álcool pode vir a fa-

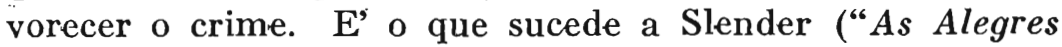
Comadres de Windsor"), embriagado e depois roubado pelos companheiros de Falstaff. E é tambem o caso do rei Duncan, assassinado por Macbeth graças ao sono etílico das sentinelas.

Um projeto de crime - projeto que não se objetiva nem inesmo como tentativa, - nasce do pifão conjunto tomado pela tríade de bêbados de "Tempestade", Estéfano, Trínculo e Caliban.

O álcool é, na opinião de Iago, uma força que impele às querelas e às ofensas (Otelo, II, iii). Apemantus, de "Timão de Atenas", preferiria que nos banquetes se usasse a água, "demasiado fraca para ser pecadora" E' que o rude filósofo desconfia dos homens e do vinho. Os que se banqueteiam com os ricos, embora exibam na face a simpatia e a amizade, matariam, si pudessem, os seus anfitriões:

\section{"Parece-me que deveriam convidá-los sem facas" (56).}

Em tais festas, beber é um perigo, já pela influência criminógena do álcool, já pelo gesto de oferecimento do pescoco, que o rico faz, quando leva o copo aos lábios:

(56) Na época de ShaKespeare, quem era convidado a um banquete devia levar a faca. 


$$
\begin{gathered}
-156- \\
\text { "Os ricos deveriam beber com um arnez no } \\
\text { pescoço" }
\end{gathered}
$$
(Timão de Atenas, I, ii)

O caldeireiro Sly, de "A Megera Domada", contém-se, quando embriagado, nos domínios da algazarra dentro da taverna e das injúrias endereçadas à taverneira. Pistol, sob a ação do vinho, apenas ameaça bater-se em duelo. Mas o caso de Cássio, em "Otelo", é mais sério: duelo e ferimentos graves.

Em "Otelo", não vê Shakespeare no álcool uma dirimente e sim uma agravante, já por se tratar, possivelmente, de embriaguez de militar em serviço, já para se pôr o poeta em harmonia com a tradição jurídica do seu país (57). Todavia, em "Henrique V", é outra a sua atitude: o joven rei, o antigo companheiro de Falstaff, perdoa certo crime gravíssimo, por haver sido praticado sob a influência do vinho:

\footnotetext{
"Meu tio Exeter, Mandai soltar o homem preso ontem,

Que atentou contra a nossa pessoa: consideramos Que foi o excesso de vinho que o impeliu".
}

(Henrique V. II, ii)

Veja-se nisto, porém, mais o gesto de magnanimidade de um jovem soberano que acaba de subir ao trono, do que a aplicação de um princípio jurídico porventura advogado pelo poeta. Para Shakespeare, de fato, o homem que sob o império da emoção ou da bebida vem a delinquir, deve ser punido pelo menos tanto quanto os outros. E' essa a tese posta por êle na boca dos senadores que condenam à morte um soldado de Alcibiades, réu de homicidio levado a efeito em estado de cólera. A despeito da eloquência do general

(57) "Quando à loucura artificial, voluntariamente adquirida por cmbriaguez ou intoxicação, a qual, privando o homem da razáo, o coloca em temporário frenesí, nossa lei a considera mais como uma agravante da ofensa do que como uma excusa de qualquer ato criminoso" (Blacristone, Commentaries on the laws of England, $10 .^{\mathrm{a}}$ ed., Londres, 1787, IV vol. pag. 25 ). 
na defesa do seu soldado, os senadores mantêm a pena de morte contra o criminoso, pois êste, por não saber dominarse, representava uma ameaça para a sociedade:

\author{
"Seus dias são turbulentos, sua embriaguez è \\ perigosa".
}

(Timão de Atenas, III, v)

No que respeita à embriaguez, os senadores do tempo de Alcibiades esposavam a doutrina de Pirtacus, o sábio governador que, quasi dois séculos antes dêles, dissera: "quem comete um crime quando bêbado, deve receber dupla punição: uma pelo próprio crime, outra pela embriaguez que o levou a cometê-lo"

Neste particular - quer em referência à emoção, quer quanto ao álcool, estão com Shakespeare e com os seus senadores (salvo, naturalmente, o radicalismo da "medida de segurança" adotada. .) quasi todos os modernos criminalistas.

\title{
DEFESA E ACUSAÇÃo
}

Si já não existe, em volume, um florilégio báquico internacional - o que é pouco provavel, - fácil será organizá-lo, abrindo-lhe as páginas, naturalmente, os nomes de grandes engenhos como Alceu e Anacreonte, Ésquilo e Aristófane, Tibulo, Horácio e Catulo (58). São dezenas, sinão centenas, os poetas que cantam os louvores do álcool.

E Shakespeare? De que lado da barricada poz êle a arma formidável do seu gênio, quando se imiscuio na multi-

(58) G. Allevi (op. cit.) dá, em seu primeiro capitulo, um breve resumo histórico da poesia báquica da Grécia, de Roma e da Itália. O dr. Legrain (Les grands narcotiques sociaux, Paris, 1925, pag. 217) encara sem indulgência êste ramo poético: "Montanhas de ditirambos foram acumulados tanto por poetas de renome como por poetastros de olho lânguido e língua pastosa". "São lamentavelmente uniformes, e a característica dessas elocubrações é a ausência de originalidade, a banalidade e o prosaismo" 
secular peleja do alcoolismo? Deixou-se arrastar, como os poetas romanos, pela onda geral que avassalava os costumes do tempo? Reagiu? Ou foi elegantemente céptico, assistindo e comentando com indiferença o desdobrar dos fatos?

"Toda cena é um combate", escreveu Voltaire. Pois combate é o teatro shakespeareano, e assim se mostra quando está em causa a embriaguez. Há o ataque e a defesa; patronos e acusadores produzem, de um e de outro lado, testemunhos e argumentos; ao tribunal, que no caso é a plateia de Shakespeare - o mundo civilizado, - exibem-se provas materiais do suposto delito; replica-se, treplica-se; e quando tudo foi pesado e refletido, vem a decisão. Mas não antecipemos.

A defesa do álcool, no teatro shakespeareano, faz-se por palavras e por atos. Quem é que toma a palavra para defendê-lo?

Um dos advogados da bebida é Caliban, o monstro, adorador do cantineiro borracho Estéfano, porque êste possue um barril de vinho, um barril de "licor celestial". Ainda assim, o grosseiro defensor mais tarde se arrependerá, quan. do vir a estupidez da sua divindade:

\section{"Que tríplice asno eu fui, \\ De tomar êste bêbado por um deus!"}

(A Tempestade, V. i)

Outro defensor é Iago, o traidor. O vinho acaba de enegrecer a vida de Cássio; e por isso mesmo foi útil aos designios de Iago. Pode êste dizer, portanto, sibilinamente:

“o vinho é um bom amigo.."

Mas acrescenta, afeito com está às restrições:

"si usado com prudência".

O terceiro advogado, o mais eloquente, é Falstaff, um imoral embotado na vida das tavernas e no convívio com os borrachos: 
"Si eu tivesse um milheiro de filhos, o primeiro principio humano que eu lhes ensinaria seria o de abster-se de bebidas fracas, e consagrar-se ao vinho"

(2 Henrique IV. IV, iv.)

Aí está a turma da defesa das bebidas alcóolicas, no teatro de SHAKESFEARE: um monstro, um traidor e um imoral.

Vamos à acusação. A tribuna se ostenta agora muito mais luzida e mais numerosa. Obriga-nos a cortezia a começar pelas damas.

Pórtia, de "Mercador de Veneza", a moça inteligente e hábil que no quarto ato é considerada, pela sua sabedoria jurídica, "um verdadeiro Daniel", acha "repugnante" o homem intoxicado pelo álcool e "tudo fará para não se casar com uma esponja"

A graciosa Violeta, de "Vésperas de Reis", quando quer enumerar uma série de defeitos graves, que mancham o homem, não se esquece da embriaguez:

"Odeio mais a ingratidão, no homem, Do que a mentira, a vaidadc, a tagarelice,

[a embriaguez,

Ou qualquer mancha de vício cuja forte corrupção Habite nosso frágil sangue.

(Véspera de Reis, III, iv)

E é ela quem inspira à sua dama de companhia a reprimenda aplicada por esta em seu primo Tobias:

"A embriaguez vos prejudica: eu ouvi minha ama conversar a respeito disso, ontem".

(Idem, I, iii)

Passemos aos homens. Apemantus, o filósofo de "Timão de Atenas", vê no álcool, como já mostramos, um revelador das tendências criminosas, considera-o um perigo social. E diz o louvor da água:

"Honesta água, que nunca afunda o homem no lodaçal”.

(Timâo de Atenas, 1, ii) 
Outro acusador está em Cesar, o futuro Augusto. A embriaguez, no seu tempo, é a regra; a sobriedade, virtude "que se aprecia nos escravos, mas não nos amigos" Demais a tirania social impele, irresistivel, para o vício. $\mathrm{Na}$ da disto, porem. o tolhe de dizer, na festa de Pompeu, que beber como o faziam os romanos, era "um trabalho monstruoso", pois consistia em "lavar o cérebro para torná-lo mais turvo"

Cássio, o nobre e afetuoso soldado, logar-tenente de Otelo, ainda sob a impressão dos males da embriaguez a que não tivera forças para fugir, exclama:

“ $O$ ' espirito invisivel do vinho, si não tens ainda nome sobre a terra, recebe o de demônio" (Otelo, II, iii)

Diga por último o torturado Hamlet, inspirado pela sua clara inteligência e sua dolorosa sensibilidade. Para êle, a embriaguez de um povo

"Rouba às suas façanhas, por elevadas que sejam, O mais precioso e mais legitimo dos seus atributos".

E o homem, embora virtuoso, pode deshonrar-se e perder-se unicamente pelo álcool, pois às vezes:

"a dracma de vinagre deshonra a inteira substância"

(Hamlet, I, iv)

A acusação ao álcool, ou, si quizerem, a defesa da temperança é, como se vê, de muito melhor quilate que a apologia da embriaguez: contra a monstruosidade e a estupidez de Caliban, a beleza, a inteligência de Pórtia e de Olívia, a penetração filosófica de Apemantus; contra a traição de Iago, a retidão de Cássio; contra a imoralidade e a indignidade de Falstaff, a sensibilidade de Hamlet, a grandeza de Augusto.

Mas além das palavras, Shakespeare apresenta pessoas e fatos. A embriaguez, para êle, é ignorante, bestial ou ridí- 
cula em Sly, em Caliban, em Estéfano, em Trinculo, em Slender; é depravada ou criminosa em Falstaff e no seu bando. Um dos seus personagens - Cássio - embora virtuoso, embriaga-se uma noite, inadvertidamente, e paga bem caro a imprudência. Os outros perdem-se no anonimato da vulgaridade ou acabam tristemente, executados pela justiça, como Bardolfo, abandonados em desgraça, como Falstaff. Não pode haver nenhuma dúvida: Shakespeare, que viu claramente as danosas consequências morais e sociais do álcool, poz ao serviço da temperança, - intencionalmente ou não, - o grande poder do seu gênio e a sutileza incomparável da sua arte.

\section{NÃO CULPEMOS AS ESTRÊLAS}

O teatro vivo e realista de Shakespeare, que espelha com fidelidade o tumulto das grandezas e das miserias humanas, abriu, para a embriaguez alcoólica, espaço proporcional ao imenso logar que ela ocupa na sociedade, e refletiu lucidamente, na cena, as opiniões e atitudes contraditórias do homem a seu respeito. Louvou e vituperou o vinho. Creou personagens que fogem ao álcool e maldizem dele; creou os que lhe cantam lôas e o procuram; e, como sóe acontecer na existência real, animou alguns que, embora acusem o tóxico, não têm energia suficiente para evitá-lo.

Mas a arte shakespeareana, essencialmente docente $e$ moralizadora, não podia ficar neutra. No conflito multisecular entre o veneno e a vida, entre a razão e o desatino, o poeta se situou em posição definida. Disse o seu pensamento e combateu por êle. Confiou a defesa da temperança aos melhores causídicos do seu fôro, abandonando aos pióres, aos ridículos, aos traidores, aos imorais, a defesa da embriaguez. Depois, com as prerrogativas de "deu's ex machina" da cena, submeteu os bebedores às mais rudes penitências, para no fim aplicar a cada um, na medida da sua sensibilidade e do seu vício, um castigo que variou entre a obscuridade do abandono e a morte ignominiosa. 
E' bem possivel que a palavra de Shakespeare tenha sido, naquela época, ouvida pelo legislador.

A $1 .^{\circ}$ de novembro de 1604, na sala de banquetes de Whitehall, em Londres, o novo rei, sucessor de Elizabeth, assistia pela primeira vez a uma peça do teatro shakespeareano. Representava-se "Otelo, o Mouro de Veneza". No segundo ato, como se sabe, Cássio maliciosamente embriagado por Iago, puxa da espada e fere seu conviva Montano. O pacífico Jaime I, a quem "a vista de uma espada fazia ficar doente", deve ter estremecido de horror perante a cena sangrenta e deve ter aplaudido sinceramente, no seu íntimo, esta frase do joven soldado:

\section{“Toda taça supérflua é criminosa, e seu con- teudo é um demônio".}

Dois anos mais tarde, em 1607, entravam em vigor os Estatutos de Jaime I, onde se incluiam, a propósito da embriaguez, preceitos considerados durante muito tempo como os fundamentos da legislação anti-alcoólica da Inglaterra.

$\mathrm{E}^{\prime}$ portanto de supor, - sem outra base, aliás, que não esta simples sucessão de fatos, - que a palavra do grande poeta, emitida da única tribuna pública daquela época, haja pesado no ânimo dos que se propuzeram disciplinar pela lei a conduta do povo inglês.

Shakespeare pintou, discutiu, combateu a embriaguez. E agora, como explicar o vício, dentro das doutrinas filosóficas do poeta? De onde vem que o homem capitule em face da tentação? E haverá, ao nosso alcance, meios com que dominar o diabólico impulso?

ShaKespeare não acredita que os homens nasçam integralmente bons. Existe neles mais de um vício inato:

$$
\begin{gathered}
\text { "vicio da natureza, } \\
\text { vindo com o nascimento, - no que êles não são } \\
\text { [culpados" } \\
(\text { Hamlet, } I, i v)
\end{gathered}
$$


O homem tem em si, certamente, debilidades ingênitas, contra as quais de pouco auxilio serão as medidas curativas da sua ciência. Mas é erro, - erro ou disfarce do comodismo moral, - admitir, por isso, que todos os nossos crimes, todos os nossos vícios, -- os quais dependem, efetivamente, de um feixe completo de fatores, - estão préviamente escritos, em letras de ferro, no livro do destino, e que, portanto, malograria tudo quanto fizéssemos em favor da nossá emenda:

“E' perfeita loucura do mundo, quando a fortuna nos é adversa, - quasi sempre por efeito de nossa própria conduta, - culpar de nossos desastres o sol, a lua e as estrêlas; como si fossemos vilões por necessidade; insensatos por pressão celeste; velhacos, ladrões e traidores por predominância das esferas; bêbados, mentirosos e adúlteros por forçada submissão às influências planetárias".

(Rei Lear, I, ii)

Não. Somos nós mesmos que conduzimos, em conjunto, o nosso destino terreno. Aceite-se, como Shakespeare expressamente o aceitou, que dependemos inicialmente do berço. Nem por isso escapamos às influências ambientais, cujos múltiplos fatores nos podem levar, dentro dos limites circunscritos pela herança, tanto à virtude como ao vício. E si não é dado ao homem alterar o seu equipamento hereditário, resta-lhe ao menos o recurso de selecionar ou modificar os elementos do meio físico e moral. O destino das sociedades humanas, como o dos indivíduos em particular, está, pois, em grande parte, dentro das mãos humanas. E' nesse sentido - e com a limitação biológica ainda longe de ser atingida - que o remédio para as nossas deficiências reside em nós mesmos, e não nos astros longínquos:

Os homens muitas vezes dominam o seu destino: Nossos erros, caro Brutus, não estão em nossa [estrêla, Mas em nós mesmos. 
Shakespfare não aceita, portanto, - como conviria aos borrachos fatalistas, - que o homem seja bêbado "por influência planetária" e não possa por isso iludir ao fado inexoràvel: a "causa" do vício tem raizes no próprio homem, e dentro dele pode ser combatida.

Quanto à "culpa", que no caso envolve, juridicamente, os conceitos de "imprudência" e "negligência", essa se distribue, em parcelas variáveis, entre o viciado, que procura o licor inebriante, e a sociedade que, tendo feito nascer o mesmo licor, e conhecendo os males do seu abuso, ainda o fabrica sem disciplina e o of erece sem medida. A noção não se encontra nos versos do poeta, mas bruxoleia dentro das consciências contemporâneas. E', pois, à sociedade, tanto quanto ao indivíduo, que podemos aplicar estas palavras de Shakespeare, nas quais se registra um fato e se aponta uma diretriz :

"nossos crimes desapareceriam si não fossem estimados pelas nossas virtudes".

(Tudo está bem quando acaba bem, IV, iii) 